\title{
Protein Kinase A Anchoring via AKAP150 Is Essential for TRPV1 Modulation by Forskolin and Prostaglandin $\mathrm{E}_{2}$ in Mouse Sensory Neurons
}

\author{
Katrin Schnizler, ${ }^{1}$ Leonid P. Shutov, ${ }^{1}$ Michael J. Van Kanegan, ${ }^{1}$ Michelle A. Merrill, ${ }^{1}$ Blake Nichols, ${ }^{2}$ \\ G. Stanley McKnight, ${ }^{2}$ Stefan Strack, ${ }^{1}$ Johannes W. Hell, ${ }^{1}$ and Yuriy M. Usachev ${ }^{1}$ \\ ${ }^{1}$ Department of Pharmacology, University of Iowa Carver College of Medicine, Iowa City, Iowa 52242, and 2Department of Pharmacology, University of \\ Washington School of Medicine, Seattle, Washington 98195
}

\begin{abstract}
Phosphorylation-dependent modulation of the vanilloid receptor TRPV1 is one of the key mechanisms mediating the hyperalgesic effects of inflammatory mediators, such as prostaglandin $\mathrm{E}_{2}\left(\mathrm{PGE}_{2}\right)$. However, little is known about the molecular organization of the TRPV1 phosphorylation complex and specifically about scaffolding proteins that position the protein kinase A (PKA) holoenzyme proximal to TRPV1 for effective and selective regulation of the receptor. Here, we demonstrate the critical role of the A-kinase anchoring protein AKAP150 in PKA-dependent modulation of TRPV1 function in adult mouse dorsal root ganglion (DRG) neurons. We found that AKAP150 is expressed in $\sim 80 \%$ of TRPV1positive DRG neurons and is coimmunoprecipitated with the capsaicin receptor. In functional studies, PKA stimulation with forskolin markedly reduced desensitization of TRPV1. This effect was blocked by the PKA selective inhibitors KT5720 [(9S,10R,12R)-2,3,9,10,11,12-hexahydro-10hydroxy-9-methyl-1-oxo-9,12-epoxy-1H-diindolo[1,2,3-fg:3', $2^{\prime}, 1^{\prime}$-kl]pyrrolo[3,4-i][1,6]benzodiazocine-10-carboxylicacid hexyl ester] and $\mathrm{H} 89$ ( $N$-[2-( $p$-bromo-cinnamylamino)-ethyl]-5-isoquinoline-sulfon-amide $2 \mathrm{HCl}$ ), as well as by the AKAP inhibitory peptide $\mathrm{Ht} 31$. Similarly, $\mathrm{PGE}_{2}$ decreased TRPV1 desensitization in a manner sensitive to the PKA inhibitor KT5720. Both the forskolin and PGE $_{2}$ effects were strongly impaired in DRG neurons from knock-in mice that express a mutant AKAP150 lacking the PKA-binding domain $(\Delta 36$ mice). Protein kinase C-dependent sensitization of TRPV1 remained intact in $\triangle 36$ mice. The $\mathrm{PGE}_{2} / \mathrm{PKA}$ signaling defect in DRG neurons from $\Delta 36$ mice was rescued by overexpressing the full-length human ortholog of AKAP150 in these cells. In behavioral testing, $\mathrm{PGE}_{2}$-induced thermal hyperalgesia was significantly diminished in $\Delta 36$ mice. Together, these data suggest that PKA anchoring by AKAP150 is essential for the enhancement of TRPV1 function by activation of the $\mathrm{PGE}_{2} / \mathrm{PKA}$ signaling pathway.
\end{abstract}

Key words: TRPV1; AKAP150; PKA; prostaglandin $\mathrm{E}_{2}$; DRG neurons; thermal hypersensitivity

\section{Introduction}

The vanilloid receptor TRPV1 is an important molecular integrator of pain-producing stimuli that is highly expressed in nociceptive $\mathrm{C}$ and $\mathrm{A} \delta$ fibers. TRPV1 functions as a transducer channel activated by noxious heat, acidic $\mathrm{pH}$, or lipid-derived endovanilloids, which enables nociceptors to respond to a range of noxious stimuli with an electrical discharge (Caterina and Julius, 2001; Szallasi et al., 2006). Studies using TRPV1 knock-out mice and TRPV1 selective antagonists have demonstrated that TRPV1 is essential for the development of inflammatory thermal hyperalgesia (Caterina et al., 2000; Davis et al., 2000; Gavva et al., 2005;

Received June 15, 2007; revised March 27, 2008; accepted March 28, 2008.

This work was supported by National Institutes of Health Grants NS054614 (Y.M.U.), NS035563 (J.W.H.), NS043254 and NS056244 (S.S.), and GM32875 and DA015916 (G.S.M.) and by an American Heart Association National Scientist Development Grant (Y.M.U.). We thank Dr. Donna Hammond for help with behavioral testing and comments on this work, Dr. William Catterall for the AKAP15 antibody, Dr. Mark Dell'Acqua for the AKAP79 and AKAP250 plasmids, Dr. John Scott for the AKAP18 plasmid, Dr. Rory Fisher for the D-AKAP2 plasmid, and Dr. Alex Kalyuzhny for providing us with the goat TRPV1 antibody.

Correspondence should be addressed to Yuriy M. Usachev, Department of Pharmacology, University of lowa Carver College of Medicine, 2-250 BSB, 51 Newton Road, lowa City, IA 52242. E-mail: yuriy-usachev@uiowa.edu. DOI:10.1523/JNEUROSCI.0233-08.2008

Copyright $\odot 2008$ Society for Neuroscience $\quad$ 0270-6474/08/284904-14\$15.00/0
Cui et al., 2006). Accordingly, TRPV1 has been functionally linked to a number of chronic pain conditions associated with inflammation, including arthritic pain, cancer pain, visceral pain, and migraine (Ghilardi et al., 2005; Jones et al., 2005; Keeble et al., 2005; Szallasi et al., 2006), and several drugs targeting TRPV1 are now in clinical trials (Immke and Gavva, 2006).

How does TRPV1 contribute to heat hyperalgesia? A key step in this process is thought to be TRPV1 sensitization by inflammatory mediators released at the site of injury, such as prostaglandins, bradykinin, and serotonin. By acting via G-proteincoupled receptors, these mediators stimulate protein kinase A (PKA) and protein kinase $\mathrm{C}$ (PKC) to induce phosphorylation of TRPV1. Phosphorylation, in turn, significantly reduces the thermal activation threshold of TRPV1, rendering nociceptors more sensitive to lower temperatures, and also sensitizes TRPV1 to capsaicin, protons, and endovanilloids (Bhave and Gereau, 2004; Nagy et al., 2004; Tominaga and Tominaga, 2005). Despite the acknowledged functional importance of TRPV1 phosphorylation, little is known about the molecular organization of the TRPV1 phosphorylation complex.

Scaffolding and adaptor proteins are central to the assembly and function of multiprotein signaling complexes. Members of 
the A-kinase anchoring protein (AKAP) family of scaffolding proteins bind the regulatory subunit of PKA and facilitate association of the enzyme with its intracellular substrates at distinct subcellular loci (Beene and Scott, 2007). Two recent reports showed that the AKAP inhibitory peptide Ht31 blocks TRPV1 sensitization in sensory neurons (Rathee et al., 2002; Sugiura et al., 2004). However, Ht31 does not discriminate among members of this large, diverse family of AKAP proteins, which differ in their tissue distribution, subcellular localization, and signaling function (Wong and Scott, 2004). Therefore, the important question of which specific AKAP regulates phosphorylation and sensitization of TRPV1 remains unanswered.

The rodent PKA-anchoring protein AKAP150, also known as AKAP79 (human ortholog), is ubiquitously expressed in the brain and is crucial for the regulation of several ion channels (Wong and Scott, 2004; Dell'Acqua et al., 2006). Here, we demonstrate that AKAP150 is coexpressed and coimmunoprecipitates with TRPV1 in mouse DRG neurons. Truncation of the last 36 residues of AKAP150, which prevents PKA binding, strongly impairs prostaglandin $\mathrm{E}_{2}\left(\mathrm{PGE}_{2}\right) / \mathrm{PKA}$-dependent modulation of TRPV1. This $\Delta 36$ knock-in phenotype is rescued by overexpressing the full-length human ortholog of AKAP150. In behavioral testing, $\mathrm{PGE}_{2}$-induced thermal hyperalgesia was significantly reduced in $\Delta 36$ mice. We conclude that AKAP150 is critically involved in the PKA-dependent regulation of TRPV1 function.

\section{Materials and Methods}

Generation and genotyping of $\Delta 36$ mice. Production and genotyping of $\Delta 36$ mice have been described recently (Lu et al., 2007). In brief, a stop codon had been engineered into the mouse AKAP150 gene to remove the PKA binding site by truncating the last 36 amino acids. Specifically, a TCTTAA sequence within the mouse AKAP150 (AKAP5) gene (GenBank locus XM138063, position 2126-2131) was mutated to TCTAGA (the stop codon is underlined). The neomycin phosphotransferase gene used for positive selection was flanked by loxP sites and removed by crossing the first generation of mutants to MEOX-cre mice. $\Delta 36$ mice showed normal growth, viability, fertility, and behavioral activity (Y. Lu, J. W. Hell, and G. S. McKnight, unpublished observation). The mutant mice were backcrossed eight times with wild-type (WT) C57BL/6 (Taconic Farms, Germantown, NY) to breed a nominally $>99 \%$ genetic C57BL/ 6 background. Homozygous breeder pairs provided $\Delta 36$ mice.

For genotyping, DNA was isolated from supernatants of RNase A- and Proteinase K-digested tail clips and was used to amplify the 3 ' coding region of AKAP150. The stop codon engineered into the mutant gene also created an $X b a \mathrm{I}$ restriction site. The primers $5^{\prime}$-AAG AAG TCT AAA AAT GTT CCT AAG- $3^{\prime}$ and $5^{\prime}$-ACC TGG AAA CGA AGT CAC TGG-3' correspond to sequences upstream and downstream of the newly created stop codon, respectively. The $400 \mathrm{bp}$ product was purified using PCR purification columns (Qiagen, Valencia, CA) and digested with XbaI. Cleaved products of 285 and 115 bp were obtained only from animals in which the engineered stop codon was present.

Cell culture and transfection. Dorsal root ganglion (DRG) neurons were obtained from adult (6-16 week old) C57BL/6 (Taconic Farms) and $\Delta 36$ mice. The animals were killed under isoflurane ( $20 \%$ in glycerol) anesthesia, according to a protocol approved by the University of Iowa Institutional Animal Care and Use Committee. DRG neurons were dissected, collected into ice-cold PBS (in mM: $1.54 \mathrm{KH}_{2} \mathrm{PO}_{4}, 155.17 \mathrm{NaCl}$, and $2.71 \mathrm{Na}_{2} \mathrm{HPO}_{4}, \mathrm{pH} 7.2$ ) and incubated at $37^{\circ} \mathrm{C}$ for $20 \mathrm{~min}$ in collagenase A $(2 \mathrm{mg} / \mathrm{ml}$; Roche Diagnostics, Indianapolis, IN) diluted with medium without serum (DMEM, $20 \mathrm{mM}$ HEPES, $0.5 \mathrm{U} / \mathrm{ml}$ penicillin, and $0.5 \mu \mathrm{g} / \mathrm{ml}$ streptomycin). Cells were washed in medium without serum and centrifuged at $750 \mathrm{rpm}$ for $3 \mathrm{~min}$ in a Hermle Z300 centrifuge with rotor 220.72 V04. Cells were digested using Pronase E $(1 \mathrm{mg} / \mathrm{ml}$; Serva, Heidelberg, Germany) for $10 \mathrm{~min}$ at $37^{\circ} \mathrm{C}$. After washing and centrifugation, cells were mechanically dissociated using flame-polished Pasteur pipettes of decreasing diameters and plated on poly-L-ornithine
(0.2 $\mathrm{mg} / \mathrm{ml}$ in $150 \mathrm{~mm}$ boric buffer) and laminin $(0.5 \mathrm{mg} / \mathrm{ml}$ in PBS; Roche Diagnostics) coated glass coverslips. Cells were grown in DMEM supplemented with $5 \%$ heat-inactivated horse serum, $5 \%$ heatinactivated fetal bovine serum, $50 \mathrm{ng} / \mathrm{ml} \mathrm{NGF}, 6 \mu \mathrm{g} / \mathrm{ml}$ insulin, $0.5 \mathrm{U} / \mathrm{ml}$ penicillin, and $0.5 \mu \mathrm{g} / \mathrm{ml}$ streptomycin, $\mathrm{pH} 7.4$, and maintained at $37^{\circ} \mathrm{C}$ in a humidified atmosphere of $5 \% \mathrm{CO}_{2}$. Experiments were performed $2 \mathrm{~d}$ after plating.

Transfection of DRG neurons was performed before plating, using an Amaxa Biosystems (Gaithersburg, MD) electroporation system. For each transfection reaction, DRG neurons obtained from one to two mice were mixed with $5 \mu \mathrm{g}$ of plasmid DNA in $100 \mu \mathrm{l}$ of Amaxa Biosystems buffer and electroporated according to the protocol of the manufacturer (program G-13). The plasmids encoding AKAP79-enhanced yellow fluorescent protein (EYFP) and AKAP250 - enhanced green fluorescent protein (EGFP) were provided by Dr. Mark Dell'Acqua (University of Colorado, Denver, CO), the AKAP15/18-EGFP plasmid was provided by Dr. John Scott (Vollum Institute, Portland, OR), and the dual specificity (D)AKAP2-EGFP plasmid was provided by Dr. Rory Fisher (University of Iowa, Iowa City, IA). D-AKAP1-EGFP was prepared by isolating the core domain of rat D-AKAP1 (residues 1-522) using reverse-transcriptase PCR and fusing to the $\mathrm{N}$ terminus of EGFP. The EYFP plasmid (pEYFPN1) was obtained from Clontech/Takara (Mountain View, CA).

Immunostaining. DRG neurons were washed in PBS followed by 20 min fixation with $4 \%$ paraformaldehyde. Cells were washed three times for 5 min each with PBS and then treated with blocking solution (5\% donkey serum and $0.1 \%$ Triton X-100 in PBS). Cells were incubated with goat polyclonal anti-TRPV1 $(10 \mu \mathrm{g} / \mathrm{ml}$; R\&D Systems, Minneapolis, MN) and rabbit polyclonal anti-AKAP150 (1:200; Upstate, Lake Placid, $\mathrm{NY}$ ) primary antibodies overnight at $4^{\circ} \mathrm{C}$. After being washed in blocking solution (five times for $5 \mathrm{~min}$ each), cells were incubated with donkey anti-goat FITC-labeled and donkey anti-rabbit tetramethylrhodamine isothiocyanate-labeled (1:200; Jackson ImmunoResearch, West Grove, PA) secondary antibodies for $30 \mathrm{~min}$ at $22^{\circ} \mathrm{C}$. Cells were subsequently washed with PBS (five times for $5 \mathrm{~min}$ each) and then mounted on slides using Fluoromount-G (Southern Biotechnology Associates, Birmingham, AL). Images were captured using an Olympus (Tokyo, Japan) BX61WI microscope equipped with the Fluoview 300 laser-scanning confocal imaging system and a $60 \times$ oil immersion objective [numerical aperture (NA), 1.40].

Immunoprecipitation and immunoblotting. Adult mouse brain, spinal cord, and dorsal root ganglia were harvested immediately after anesthesia and decapitation of C57BL/6 mice. Tissues were homogenized in ice-cold buffer containing 50 mм Tris-HCl, pH 7.4, 150 mм NaCl, 5 mм EDTA, 1 mм EGTA, and $1 \%$ Triton X-100 and supplemented with protease inhibitors $(1 \mu \mathrm{g} / \mathrm{ml}$ pepstatin $\mathrm{A}, 10 \mu \mathrm{g} / \mathrm{ml}$ leupeptin, $20 \mu \mathrm{g} / \mathrm{ml}$ aprotinin, and $200 \mathrm{~nm}$ phenylmethanesulfonyl fluoride). Nonsolubilized material was pelleted for $30 \mathrm{~min}$ at 40,000 rpm in a Beckman Ti-70 rotor (Beckman Coulter, Fullerton, CA). To determine expression profiles of different AKAP subtypes in mouse nervous tissue, protein concentration was estimated by a BCA assay, and $50 \mu \mathrm{g}$ of protein was loaded on the gels. Protein was extracted by boiling in SDS sample buffer, separated by SDS-PAGE, transferred to polyvinylidene fluoride membranes $(0.45$ $\mu \mathrm{m}$; Millipore, Billerica, MA), and probed for the presence of AKAP isoforms. Rabbit anti-AKAP15 antibody (1:1000 dilution) was a generous gift from Dr. William Catterall (University of Washington, Seattle, WA), rabbit anti-AKAP150 antibody (1:1000 dilution) was from Upstate (Lake Placid, NY), mouse anti-AKAP250 antibody (1:2000 dilution) was from Abcam (Cambridge, MA), and rabbit anti-Yotiao antibody (1:250 dilution) was from Zymed Laboratories (Carlsbad, CA). TRPV1-AKAP complexes were detected by immunoprecipitating TRPV1 from spinal cord lysates (five animals per experiment) or DRG lysates (three to six animals per experiment) using $3 \mu \mathrm{g}$ of rabbit anti-TRPV1 antibody (catalog \#RA14113; Neuromics, Edina, MN) and $30 \mu \mathrm{l}$ of prewashed protein-A beads ( $\sim 50 \%$ slurry; Santa Cruz Biotechnology, Santa Cruz, CA) for $4 \mathrm{~h}$; immunoprecipitates were washed three times with $0.1 \%$ Triton X-100 in TBS (20 mm Tris- $\mathrm{HCl}$ and $150 \mathrm{~mm} \mathrm{NaCl}$ ). Probing was done using the Neuromics anti-TRPV1 antibody (1:500 dilution) and the various anti-AKAP antibodies listed above. Specificity of the TRPV1 antibody was confirmed by blotting immunoprecipitates with other TRPV1 
antibodies either from Neuromics (N-terminus rabbit anti-TRPV1) or from Calbiochem (San Diego, CA) (Ab-2 rabbit anti-TRPV1). Association of PKA with AKAP150 was detected by immunoprecipitating AKAP150 from spinal cord lysate and probing with the rabbit anti-PKA RII $\alpha$ antibody (M-20) (1:500 dilution; Santa Cruz Biotechnology). TRPV1-PKA association was examined by immunoprecipitating TRPV1 with $3 \mu \mathrm{g}$ of the goat anti-TRPV1 antibody (R\&D Systems, Minneapolis, MN) and probing for PKA RII $\alpha$. Control immunoprecipitations were performed with $3 \mu \mathrm{g}$ of purified rabbit (Zymed Laboratories) or goat IgG that originated from nonimmunized animals (Jackson ImmunoResearch).

Calcium imaging. The standard extracellular HEPES-buffered HBSS ( $\mathrm{HH}$ buffer) contained the following (in $\mathrm{mM}$ ): $140 \mathrm{NaCl}, 5 \mathrm{KCl}, 1.3$ $\mathrm{CaCl}_{2}, 0.4 \mathrm{MgSO}_{4}, 0.5 \mathrm{MgCl}_{2}, 0.4 \mathrm{KH}_{2} \mathrm{PO}_{4}, 0.6 \mathrm{NaHPO}_{4}, 3 \mathrm{NaHCO}_{3}, 10$ glucose, and 10 HEPES, pH 7.35 with $\mathrm{NaOH}(310 \mathrm{mOsm} / \mathrm{kg}$ with sucrose). DRG neurons were incubated for 25 min with $2 \mu \mathrm{M}$ of the AM form of fura- 2 at room temperature $\left(22^{\circ} \mathrm{C}\right)$. Cells were placed in a flowthrough chamber mounted on the stage of an inverted IX-71 microscope (Olympus) and washed for $10 \mathrm{~min}$ before the experiment. Fluorescence was alternately excited at 340 (12 nm bandpass) and 380 (12 nm bandpass) using the Polychrome IV monochromator (T.I.L.L. Photonics, Martinsried, Germany), via either a $20 \times$ objective (NA 0.75; Olympus) or a $40 \times$ oil immersion objective (NA 1.35; Olympus). Emitted fluorescence was collected at 510 (80) $\mathrm{nm}$ using an IMAGO CCD camera (T.I.L.L. Photonics). Pairs of $340 / 380 \mathrm{~nm}$ images were sampled at $0.2 \mathrm{~Hz}$. The fluorescence ratio $\left(R=F_{340} / F_{380}\right)$ was converted to $\left[\mathrm{Ca}^{2+}\right]_{\mathrm{i}}$ according to the formula $\left[\mathrm{Ca}^{2+}\right]_{\mathrm{i}}=K_{\mathrm{d}} \beta\left(R-R_{\min }\right) /\left(R_{\max }-R\right)$ (Grynkiewicz et al., 1985). The dissociation constants $\left(K_{\mathrm{d}}\right)$ used for fura- 2 was $225 \mathrm{~nm}$ (Invitrogen Handbook; Invitrogen, Carlsbad, CA). $R_{\min }, R_{\max }$, and $\beta$ were determined by applying $10 \mu \mathrm{M}$ ionomycin in $\mathrm{Ca}^{2+}$-free buffer $(1 \mathrm{mM}$ EGTA) and HH buffer $\left(1.3 \mathrm{mM} \mathrm{Ca}^{2+}\right)$. Calibration constants for the $20 \times$ objective were as follows: $R_{\min }=0.21, R_{\max }=3.45$, and $\beta=6.97$. For the $40 \times$ objective, calibration constants were as follows: $R_{\min }=0.17, R_{\max }=$ 2.71 , and $\beta=5.64$. Fluorescence was corrected for background, as determined in an area that did not contain a cell. Data were processed using TILLvisION 4.0.1.2 (T.I.L.L. Photonics) and Origin 7.0 (Microcal Software, Northhampton, MA) software and presented as mean \pm SEM.

Electrophysiology. Whole-cell patch-clamp recordings ( $V_{\text {hold }}$ of -60 $\mathrm{mV}$ ) were obtained using a patch-clamp amplifier Axopatch 200B and an analog-to-digital converter Digidata 1322A (Molecular Devices, Union City, CA). Patch pipettes were pulled from borosilicate glass (3-5 M $\Omega$; Narishige, Tokyo, Japan) on a P-87 micropipette puller (Sutter Instruments, Novato, CA) and filled with the following solution (in $\mathrm{mM}$ ): 125 K-gluconate, $10 \mathrm{KCl}, 10 \mathrm{NaCl}, 0.5 \mathrm{Na}-\mathrm{GTP}, 3 \mathrm{Mg}-\mathrm{ATP}, 1 \mathrm{MgCl}_{2}, 0.2$ EGTA, and 10 HEPES, pH 7.25 adjusted with $\mathrm{KOH}(290 \mathrm{mOsm} / \mathrm{kg}$ with sucrose). The standard extracellular recording solution contained the following: $50 \mathrm{~mm} \mathrm{NaCl}, 90 \mathrm{~mm}$ choline- $\mathrm{Cl}, 5 \mathrm{~mm} \mathrm{KCl}, 1.3 \mathrm{~mm} \mathrm{CaCl}_{2}, 0.4$ mм MgSO $, 0.5 \mathrm{~mm} \mathrm{MgCl}_{2}, 0.4 \mathrm{~mm} \mathrm{K \textrm {K } _ { 2 }} \mathrm{PO}_{4}, 0.6 \mathrm{~mm} \mathrm{Na}_{2} \mathrm{HPO}_{4}, 3 \mathrm{~mm}$ $\mathrm{NaHCO}_{3}, 10 \mathrm{~mm}$ glucose, $10 \mathrm{~mm}$ HEPES, and $1 \mu \mathrm{m}$ tetrodotoxin, pH 7.35 with $\mathrm{NaOH}(310 \mathrm{mOsm} / \mathrm{kg}$ with sucrose). Heat-evoked currents were induced by superfusing cells with preheated solution, which enabled a temperature increase from room temperature to $\sim 48^{\circ} \mathrm{C}$ at a rate of $1.2-$ $1.6^{\circ} \mathrm{C} / \mathrm{s}$. Temperature was monitored by using a bead thermistor TA-29 (Warner Instruments, Hamden, CT) positioned within $100 \mu \mathrm{m}$ from the cell and connected to a single-channel heater controller TC-324BHT (Warner Instruments). Data were collected (filtered at $1 \mathrm{kHz}$ and sampled at $2.5 \mathrm{kHz}$ ) and analyzed using the pClamp 9 software (Molecular Devices) and presented as mean \pm SEM.

Behavioral testing. All experiments were performed in male adult (8-12 week old) C57BL/6 (Taconic Farms) and $\Delta 36$ mice using a protocol approved by the University of Iowa Institutional Animal Care and Use Committee. Every effort was made to minimize the number of mice and their suffering. Thermal sensitivity was examined by measuring pawwithdrawal latency in response to a radiant heat stimulus applied to the plantar surface of the hindpaw (Hargreaves et al., 1988). Time to pawwithdrawal reflex was determined electronically. Mice were acclimated to the testing room and equipment for $3 \mathrm{~d}(2 \mathrm{~h} / \mathrm{d})$ and also for at least $1 \mathrm{~h}$ before testing. $\mathrm{PGE}_{2}(100 \mathrm{ng}$ ) was injected subcutaneously into the plantar surface of one hindpaw in a volume of $10 \mu \mathrm{l}$. In some experiments,
Ht31 $(8 \mu \mathrm{g})$ was coinjected with $\mathrm{PGE}_{2}$ in the same total volume of $10 \mu \mathrm{l}$. Paw-withdrawal latency was measured at 15, 30, 60, and 90 min after the injection. The baseline latency was determined before the injection by averaging the results of three tests separated by a $5 \mathrm{~min}$ interval. Mice were used only once and received only one dose of drug or drug combination.

Reagents. Capsaicin, forskolin, 8-pCPT-2'-O-Me-cAMP (CPTOMe), U73122 (1-[6[[(17 $\beta)$-3-methoxyestra-1,3,5(10)-trien-17-yl]amino]hexyl]-1 $H$-pyrrole-2,5-dione), and tetrodotoxin were purchased from Tocris (Ellisville, MO), membrane-permeable stearated forms of the $\mathrm{Ht} 31$ and Ht31P peptides were obtained from Promega (Madison, WI), phorbol-12,13-dibutyrate $(\mathrm{PdBu})$ and $\mathrm{PGE}_{2}$ were from Calbiochem, KT5720 [(9S,10R,12R)-2,3,9,10,11,12-hexahydro-10-hydroxy-9-methyl1-oxo-9, 12-epoxy- $1 \mathrm{H}$-diindolo[ $1,2,3$-fg:3',2', $1^{\prime}$-kl]pyrrolo[3,4-i] [1,6] benzodiazocine-10-carboxylicacid hexyl ester] was from Alomone Labs (Jerusalem, Israel), and fura-2 AM was from Invitrogen. All other reagents were from Sigma (St. Louis, MO).

\section{Results}

\section{TRPV1 and AKAP150 are coexpressed and}

\section{coimmunoprecipitate in DRG neurons}

To identify PKA anchoring proteins that could potentially interact with TRPV1, we first examined which AKAPs are expressed in DRG and the spinal cord of adult mice. Both DRG and the spinal cord are rich in TRPV1, in which the receptor is found on the cell bodies and on the central processes of primary nociceptors, respectively (Tominaga et al., 1998; Guo et al., 1999; Caterina et al., 2000; Malin et al., 2006). We studied expression of four different AKAPs that have been shown to associate with other ion channels and receptors: AKAP15/18, AKAP150, AKAP250, and Yotiao (Wong and Scott, 2004). Immunoblots obtained from DRG and spinal cord lysates were compared with those obtained from brain, in which these AKAPs have been characterized previously (Tibbs et al., 1998; Westphal et al., 1999; Colledge et al., 2000; Piontek and Brandt, 2003; Hall et al., 2007; Lu et al., 2007).

Probing with an anti-AKAP15/18-specific antibody revealed two strongly immunoreactive bands in lysates from brain and DRG and one in spinal cord lysate (Fig. 1A). The AKAP15/18 gene (Gene Nomenclature Committee name AKAP7) is subject to splicing, which gives rise to the lower molecular weight $(15 / 18$ $\mathrm{kDa} \alpha$ and $\beta$ isoforms that are targeted to the cell membrane and to a higher molecular weight $(\sim 35 \mathrm{kDa}) \gamma$ isoform that is cytoplasmic (Trotter et al., 1999). In the brain, AKAP15/18 was shown to associate with voltage-gated $\mathrm{Na}^{+}\left(\mathrm{Na}_{\mathrm{v}} 1.2 \mathrm{a}\right)$ and $\mathrm{Ca}^{2+}$ $\left(\mathrm{Ca}_{\mathrm{v}} 1.2\right)$ channels (Tibbs et al., 1998; Cantrell et al., 2002; Hall et al., 2007). AKAP15/18 is also expressed in cardiac and skeletal muscles, in which it interacts with the L-type $\mathrm{Ca}^{2+}$ channel to facilitate PKA-dependent phosphorylation of the channel (Gray et al., 1997, 1998; Fraser et al., 1998; Hulme et al., 2003).

As shown in Figure 1 A, AKAP150 (Gene Nomenclature Committee name AKAP5; also known as AKAP79) is robustly expressed in the spinal cord and DRG. Previous studies showed that AKAP79/150 is abundant at the postsynaptic sites of glutamatergic synapses in which it facilitates PKA-dependent phosphorylation of AMPA and NMDA glutamate receptors, thereby contributing to synaptic plasticity (Colledge et al., 2000; Gomez et al., 2002; Lu et al., 2007). AKAP79/150 also associates with the L-type $\left(\mathrm{Ca}_{\mathrm{v}} 1.2\right) \mathrm{Ca}^{2+}$ channels (Gao et al., 1997; Hall et al., 2007), M-type (KCNQ2/3) $\mathrm{K}^{+}$channels (Hoshi et al., 2003), ASIC1a and $2 \mathrm{a}$ channels (Chai et al., 2007), and $\beta 2$-adrenergic receptor (Fraser et al., 2000).

We found that AKAP250, also known as gravin (Gene Nomenclature Committee name AKAP12), is expressed in both spinal cord and DRG, whereas the AKAP Yotiao, which is a $\sim 230$ 

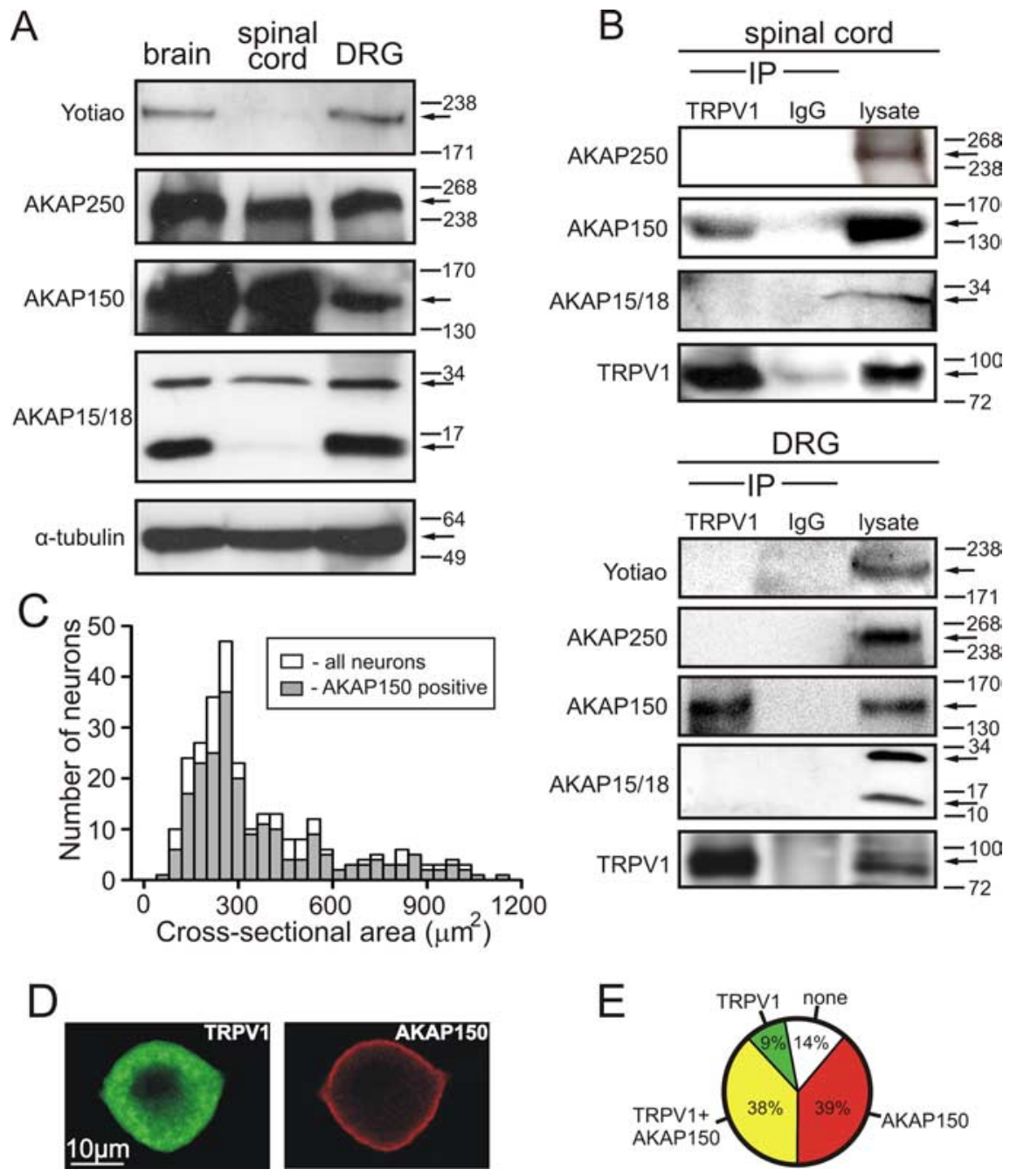

Figure 1. AKAP150 is associated with TRPV1 in DRG neurons. A, DRG neurons express multiple AKAPs. Western blots of lysates of adult mouse brain, spinal cord, and DRG tissue were probed with antibodies against Yotiao, AKAP250, AKAP150, AKAP15/18, and $\alpha$-tubulin, respectively (3-5 independent experiments, 12-20 animals). B, AKAP150-TRPV1 complexes were isolated from adult mouse spinal cord (top) and DRG (bottom) membrane fractions. Immunoprecipitations (IP) were performed with an antibody against TRPV1 or control IgG. Immunoprecipitates were separated by SDS-PAGE and probed with antibodies against Yotiao, AKAP250, AKAP150, AKAP15/18, and TRPV1, respectively (spinal cord: 5 independent experiments, 27 animals; DRG: 9 independent experiments, 40 animals). C, Histogram shows size (cross-sectional area of the cell body) distribution of AKAP150-positive DRG neurons relative to all neurons. D, Immunostaining shows subcellular distribution of TRPV1 (left) and AKAP150 (right) in a DRG neuron expressing both proteins. E, Pie chart shows the proportion of DRG neurons expressing AKAP150 (red), TRPV1 (green), both proteins (yellow), or none (white) in culture.

$\mathrm{kDa}$ splice variant of the AKAP450 gene (Gene Nomenclature Committee name AKAP 9), is expressed in DRG but undetectable in spinal cord lysate (Fig. 1 A). Like AKAP150 (Fraser et al., 2000), AKAP250 assembles with the $\beta_{2}$-adrenergic receptor (Shih et al., 1999; Tao et al., 2003). Yotiao interacts with the NMDA (NR1A subunit) receptor in the brain (Lin et al., 1998; Westphal et al., 1999) and also associates with and facilitates phosphorylation of the slow $\mathrm{K}^{+}$channel $I_{\mathrm{Ks}}$ in the heart (Kurokawa et al., 2004).

We next examined which of these AKAPs interact with TRPV1. Using a TRPV1-specific antibody, we found that only AKAP150, but not any other tested AKAP, coimmunoprecipitated with the TRPV1 channel in spinal cord and DRG. Immunoblots of TRPV1 immunoprecipitates revealed that AKAP150 specifically and reproducibly (five independent experiments using spinal cord from 27 animals and nine experiments using DRG from 40 animals) associated with TRPV1 (Fig. $1 B$ ). Coimmunoprecipitation of AKAP150 with TRPV1 was specific, because nonimmune control antibodies failed to isolate either of these proteins (IgG lanes in Fig. $1 B$ ).

Immunostaining revealed that AKAP150 is expressed in $\sim 77 \%$ of DRG neurons (303 of 394), present in all size groups, and its expression pattern matches the overall size distribution (Fig. 1C). TRPV1 is expressed in $~ 47 \%$ of DRG neurons (185 of 394), consistent with observations by others (Negri et al., 2006; Wang et al., 2006; Hjerling-Leffler et al., 2007). The majority of TRPV1-expressing cells ( 80\%) also showed AKAP150 immunofluorescence that was highly concentrated near the plasma membrane (Fig. $1 D$, red). Approximately 39\% of DRG neurons showed immunostaining for AKAP150 but not for TRPV1 (154 of 394), whereas $\sim 14 \%$ showed neither AKAP150 nor TRPV1 immunofluorescence (55 of 394) (Fig. 1E).

\section{Disruption of PKA anchoring by AKAP150 inhibits PKA-dependent modulation of TRPV1}

TRPV1 function is strongly dependent on its phosphorylation state. The receptor is at least partially phosphorylated in the resting state (Bhave et al., 2002; Mandadi et al., 2006). TRPV1 is highly permeable for $\mathrm{Ca}^{2+}\left[P_{\mathrm{Ca}} / P_{\mathrm{Na}}=9.6\right.$ (Caterina et al., 1997)], and $\mathrm{Ca}^{2+}$ influx via TRPV1 induces $\mathrm{Ca}^{2+} /$ calcineurin-dependent dephosphorylation and desensitization of the receptor (Cholewinski et al., 1993; Koplas et al., 1997; Mohapatra and Nau, 2005). In turn, phosphorylation by PKA prevents desensitization of TRPV1 and enhances its function (Bhave et al., 2002; Mohapatra and Nau, 2003, 2005). To study TRPV1 regulation by PKA, we adapted the desensitization protocols developed by several other groups (Hu et al., 2002; Yang and Gereau, 2002; Mohapatra and Nau, 2003; Mandadi et al., 2004). Capsaicin-induced $\mathrm{Ca}^{2+}$ influx was measured by using $\mathrm{Ca}^{2+} \mathrm{im}^{2}$ aging, which has been established as a reliable tool to monitor TRPV1 activity in intact neurons (Caterina et al., 1997; Greffrath et al., 2001; Savidge et al., 2001; Hu et al., 2002; Malin et al., 2006).

First, we examined the time course of TRPV1 desensitization (tachyphylaxis) in adult mouse DRG neurons by studying changes in cytosolic $\mathrm{Ca}^{2+}$ concentration $\left(\left[\mathrm{Ca}^{2+}\right]_{\mathrm{i}}\right)$ induced by two successive capsaicin applications ( $100 \mathrm{~nm}$ for $10 \mathrm{~s}$ ). Stimulations with capsaicin were separated by various time intervals ranging from 3 to $60 \mathrm{~min}$ (Fig. 2). Cells were included in additional analysis only if, during capsaicin stimulation, they showed an elevation in $\left[\mathrm{Ca}^{2+}\right]_{\mathrm{i}}$ that was at least $100 \%$ higher than the basal $\left[\mathrm{Ca}^{2+}\right]_{\mathrm{i}}$ and if the $\left[\mathrm{Ca}^{2+}\right]_{\mathrm{i}}$ after the first or second capsaicin application reached at least $150 \mathrm{nM}$. Desensitization was quantified as the response ratio $=A_{2} / A_{1}$, where $A_{1}$ and $A_{2}$ are the amplitudes of $\left[\mathrm{Ca}^{2+}\right]_{\mathrm{i}}$ changes induced by the first and second capsaicin application, respectively (Hu et al., 2002; Yang and Gereau, 

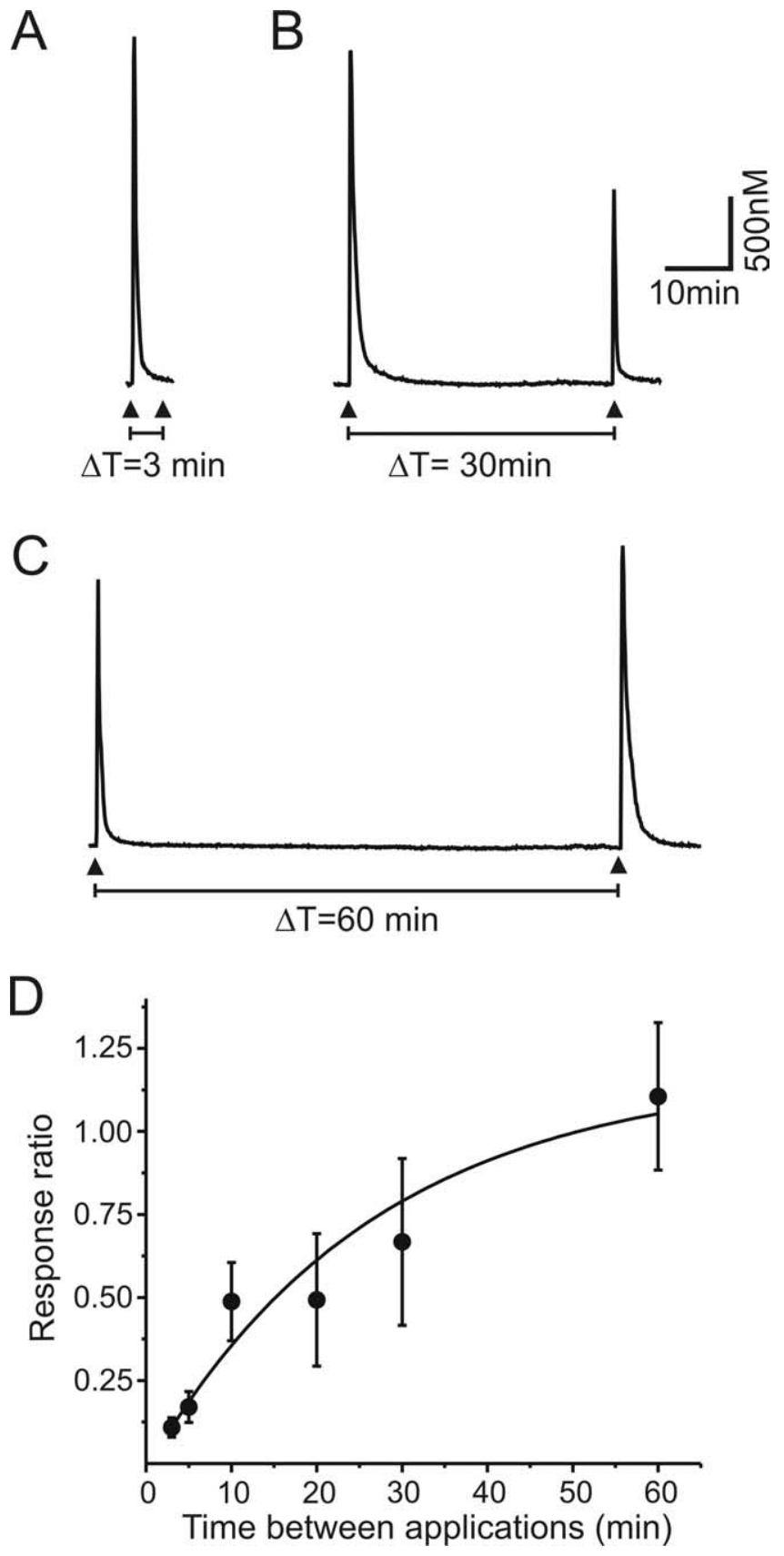

Figure 2. Time dependence of TRPV1 recovery from desensitization in a paired-pulse stimulation protocol. $A-C,\left[\mathrm{Ca}^{2+}\right]_{\mathrm{i}}$ transients were evoked by two applications of capsaicin $(100 \mathrm{~nm}$ for $10 \mathrm{~s}$; indicated by arrowheads), which were separated by $3 \mathrm{~min}(A), 30 \mathrm{~min}(\boldsymbol{B})$, or $60 \mathrm{~min}(\boldsymbol{C})$. $D$, Plot of the response ratio (Amplitude ${ }_{2} /$ Amplitude $_{1}$ ) as a function of the time interval between two capsaicin applications. Data are presented as mean \pm SEM and were obtained from 13-51 cells from 4-14 animals for each time point. Data points were fitted with a singleexponential function (smooth curve) using a nonlinear, least-squares curve fitting algorithm (Origin 7 software).

2002). We found that TRPV1 channels were strongly desensitized when two capsaicin applications were separated by only $3 \mathrm{~min}$ (Fig. $2 \mathrm{~A}$ ); the response ratio under these conditions was $0.11 \pm$ 0.03 ( $n=51$ cells/14 animals). As shown in Figure 2, TRPV1 slowly recovered from desensitization, and the $\left[\mathrm{Ca}^{2+}\right]_{\mathrm{i}}$ response to capsaicin was fully restored within an hour (response ratio, $1.11 \pm 0.22 ; n=22$ cells $/ 4$ animals).

For additional studies, we chose the $3 \mathrm{~min}$ protocol, for which TRPV1 channels are most strongly desensitized under control conditions (Fig. 3A). Desensitization of TRPV1 was markedly reduced by the treatment of cells with $10 \mu \mathrm{M}$ forskolin, an activator of adenylate cyclase and thereby PKA (response ratio, $0.51 \pm$ $0.09 ; n=73$ cells $/ 14$ animals) (Fig. $3 B, G$ ). Pretreating DRG neurons with the PKA-selective inhibitors H89 ( $N$-[2-( $p$-bromocinnamylamino)-ethyl]-5-isoquinoline-sulfon-amide $2 \mathrm{HCl})(10$ $\mu \mathrm{M})$ (Fig. 3C) or KT5720 (1 $\mu \mathrm{M})$ (Fig. 3D) blocked the forskolin effect on TRPV1, reducing the response ratio to $0.12 \pm 0.05(n=$ 20 cells $/ 6$ animals) (Fig. $3 C, G)$ and $0.17 \pm 0.05(n=36$ cells $/ 4$ animals) (Fig. $3 D, G$ ), respectively. Preincubation with these inhibitors had no effect on either the amplitude of the $\left[\mathrm{Ca}^{2+}\right]_{\mathrm{i}}$ response to the first capsaicin application $(1360 \pm 320 \mathrm{~nm}$ in control, $n=51$ cells/ 12 animals; $2190 \pm 550 \mathrm{nM}$ for H89, $n=23$ cells/2 animals; $1280 \pm 250 \mathrm{nM}$ for KT5720, $n=17$ cells $/ 4$ animals; $p>0.05$, one-way ANOVA with Bonferroni's post hoc test) or TRPV1 desensitization in cells that had not been treated with forskolin (response ratio, $0.11 \pm 0.03$ in control, $n=51$ cells $/ 12$ animals; response ratio, $0.08 \pm 0.04$ for $\mathrm{H} 89, n=23$ cells $/ 2$ animals; response ratio, $0.07 \pm 0.03$ for KT5720, $n=17$ cells $/ 4$ animals; $p>0.05$, one-way ANOVA with Bonferroni's post hoc test).

Forskolin-induced increase of cAMP concentration could also potentially lead to activation of Epac (guanine exchange protein activated by cAMP) (Holz et al., 2006). Epac, in turn, has been linked to phospholipase C (PLC)-dependent activation of $\mathrm{PKC} \varepsilon$ in sensory neurons (Hucho et al., 2005). However, we found that addition of the specific Epac activator CPTOMe (10 $\mu \mathrm{M})$ to the extracellular solution before the second capsaicin application had no effect on TRPV1 desensitization. The response ratio for the CPTOMe-treated cells was $0.16 \pm 0.06(n=39$ cells/2 animals), which was not significantly different from that in control (untreated) cells (Fig. $3 A, G)(p>0.05$, one-way ANOVA with Bonferroni's post hoc test). Moreover, the forskolin-induced reduction in desensitization was not affected by treating cells with the PLC inhibitor U73122 ( $1 \mu \mathrm{M} ; 10 \mathrm{~min}$ pretreatment). The response ratio for the cells treated with a combination of $10 \mu \mathrm{M}$ forskolin and $1 \mu \mathrm{M}$ U73122 was $0.46 \pm$ 0.11 ( $n=65$ cells $/ 3$ animals). This is not significantly different from the response ratio obtained for cells treated with forskolin alone (Fig. $3 B, G)(p>0.05$, one-way ANOVA with Bonferroni's post hoc test). These data, together with the findings that two structurally different PKA inhibitors, H89 and KT5720, completely blocked the effect of forskolin, suggest that forskolininduced reduction of TRPV1 desensitization was mediated primarily by PKA.

We next examined the role of PKA signaling in the immediate vicinity of TRPV1. Functional coupling of PKA to its cellular substrates is mediated by AKAP proteins (Wong and Scott, 2004; Dell'Acqua et al., 2006). The Ht31 peptide encompasses the PKA regulatory subunit binding site of AKAPs and is widely used to competitively dissociate PKA/AKAP complexes. Ht31 has been shown to redistribute a pool of PKA holoenzymes from the cell membrane to the cytoplasm (Hundsrucker et al., 2006). Preincubation of cells with a membrane-permeable stearated form of the $\mathrm{Ht} 31$ peptide $(50 \mu \mathrm{M})$ abolished the forskolin effect on TRPV1, reducing the response ratio to $0.12 \pm 0.05(n=17$ cells $/ 6$ animals) (Fig. $3 E, G$ ). In contrast, treatment with the control Ht31P peptide, which contains two amino acid substitutions that abrogate the binding to PKA, did not interfere with the effect of forskolin (response ratio, $0.65 \pm 0.15 ; n=11$ cells $/ 4$ animals) (Fig. $3 F, G)$.

Next, we specifically addressed the role of PKA anchoring by AKAP150 in PKA-mediated reduction of TRPV1 desensitization. 


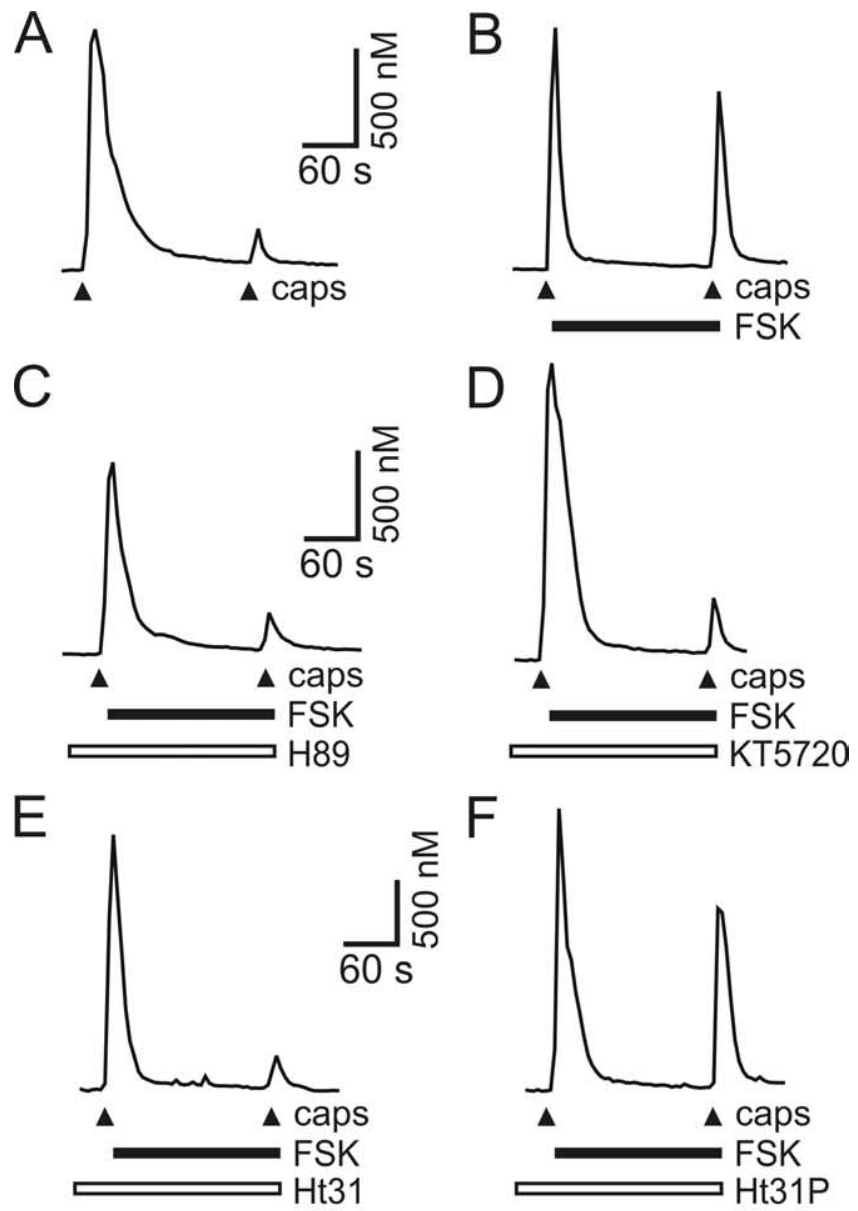

G

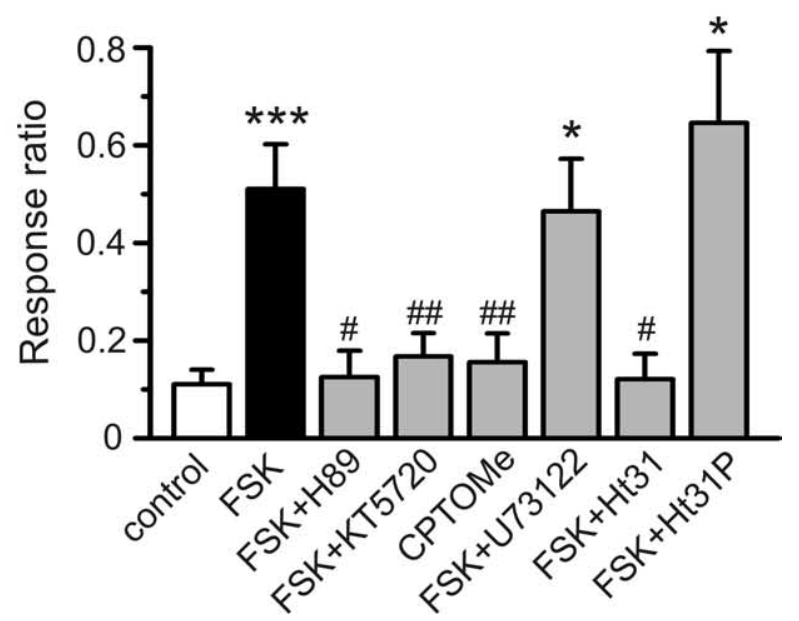

Figure 3. Forskolin reduces TRPV1 desensitization in a PKA- and AKAP-dependent manner. $\boldsymbol{A}-\boldsymbol{F},\left[\mathrm{Ca}^{2+}\right]_{\mathrm{i}}$ changes in DRG neurons were evoked by two subsequent capsaicin applications (100 nM for $10 \mathrm{~s}, 3 \mathrm{~min}$ between the applications indicated by arrowheads) under control conditions ( $\mathrm{HH}$ buffer; $\boldsymbol{A}$ ) and during treatments with $10 \mu \mathrm{m}$ forskolin (FSK; $\boldsymbol{B}$ ), $10 \mu \mathrm{m}$ forskolin and $10 \mu \mathrm{M} \mathrm{H89} \mathrm{(C),} 10 \mu \mathrm{m}$ forskolin and $1 \mu \mathrm{M} \mathrm{KT} 5720$ (D), $10 \mu \mathrm{m}$ forskolin and $50 \mu \mathrm{M} \mathrm{Ht} 31$ (E),

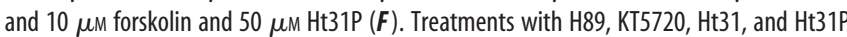
started $20 \mathrm{~min}$ before the first capsaicin application and were continued throughout the experiments as indicated by the horizontal bars. $\mathbf{G}$, Bar graph summarizes the effects of forskolin (10 $\mu \mathrm{M} ;$ FSK), the PKA inhibitors H89 $(10 \mu \mathrm{M})$ and KT5720 $(1 \mu \mathrm{M})$, the Epac activator CPTOMe (10 $\mu \mathrm{M})$, the PLC inhibitor U73122 $(1 \mu \mathrm{m})$, and AKAP inhibitory peptides (Ht31 or Ht31P at $50 \mu \mathrm{M}$ ) on TRPV1 desensitization in DRG neurons from WT mice. Data were obtained from experiments such as those shown in $\boldsymbol{A}-\boldsymbol{F}$ and are presented as mean \pm SEM. ${ }^{*} p<0.05$ and ${ }^{* * *} p<0.001$ relative to control; ${ }^{\#}<<0.05$ and ${ }^{\# \#} p<0.01$ relative to forskolin treatment alone; one-way ANOVA with Bonferroni's post hoc test.
AKAP150 contains binding sites for PKA, PKC, and calcineurin (Fig. 4A) and is involved in regulating AMPA receptors, M-type $\mathrm{K}^{+}$and L-type $\mathrm{Ca}^{2+}$ channels, and acid sensing ion channels (Gao et al., 1997; Tavalin et al., 2002; Hoshi et al., 2003; Chai et al., 2007; Hall et al., 2007). We have recently described $\Delta 36$ knock-in mice, in which WT AKAP150 is replaced by a mutant that is truncated by 36 residues to specifically remove the PKA binding domain (Fig. 4A) (Lu et al., 2007). Coimmunoprecipitation using an AKAP150-specific antibody shows that PKA association with AKAP150 is indeed disrupted in these mice (Fig. 4B). Furthermore, immunoprecipitation using a TRPV1-specific antibody demonstrates that both AKAP150 and the PKA regulatory subunit PKA RII $\alpha$ associate with TRPV1 in WT mice. In contrast, the PKA-TRPV1 interaction was disrupted in $\Delta 36$ mice, although the mutant AKAP150- $\Delta 36$ protein was still present in the immunoprecipitation complex (Fig. 4C). These data are consistent with the idea that PKA association with TRPV1 is mediated by AKAP150.

The functional significance of AKAP150 was tested by studying TRPV1 desensitization in DRG neurons from homozygous $\Delta 36$ mice using the 3 min capsaicin paired-pulse protocol described in Figure 3. Amplitudes of $\left[\mathrm{Ca}^{2+}\right]_{\mathrm{i}}$ responses to the first capsaicin application were no different between DRG neurons from WT and $\Delta 36$ mice (WT, $1360 \pm 320 \mathrm{nM}, n=51$ cells $/ 12$ animals; $\Delta 36,1200 \pm 170 \mathrm{nM}, n=47$ cells $/ 10$ animals; $p=0.68$, Student's $t$ test). TRPV1 desensitization was also similar in DRG neurons from WT and $\Delta 36$ mice under control conditions (Fig. $4 D, F)$. However, forskolin revealed a striking difference between DRG neurons from WT and $\Delta 36$ mice. We found that the ability of forskolin to prevent TRPV1 desensitization was strongly impaired in DRG neurons from $\Delta 36$ mice (Fig. $4 E, F$ ), yielding a response ratio of only $0.20 \pm 0.05$ ( $n=45$ cells/ 10 animals); the response ratio was not significantly changed by pretreating cells with the PKA inhibitor KT5720 (Fig. 4F). Thus, PKA anchoring by AKAP150 is crucial for PKA-mediated reduction of TRPV1 desensitization in DRG neurons.

\section{PKC-dependent sensitization of TRPV1 is unaltered in DRG} neurons from $\Delta 36$ mice

Phosphorylation by PKC sensitizes TRPV1 to heat, protons, capsaicin, and endovanilloids (Premkumar and Ahern, 2000; Vellani et al., 2001; Numazaki et al., 2002; Bhave et al., 2003; Premkumar et al., 2004; Gold and Flake, 2005). AKAP150 also directly binds $\mathrm{PKC}$ to bring the kinase in close proximity to its ion channel and receptor substrates (Wong and Scott, 2004). The PKC-binding site is located near the N terminus of AKAP150 (Dell'Acqua et al., 2006). Therefore, truncation of the PKA binding site at the $C$ terminus of AKAP150 in $\Delta 36$ mice (Fig. $4 A$ ) is not expected to interfere with PKC binding to AKAP150. To examine whether the PKC-dependent pathway remains functional in DRG neurons from $\Delta 36$ mice, we compared the effects of PKC stimulation on capsaicin-induced $\left[\mathrm{Ca}^{2+}\right]_{\mathrm{i}}$ responses in cells from WT and $\Delta 36$ mice. We used the same $3 \mathrm{~min}$ paired-pulse protocol as described above (Figs. 3, 4). We found that PKC stimulation using $500 \mathrm{~nm} \mathrm{PdBu}$ strongly sensitized TRPV1 to capsaicin in DRG neurons from both WT and $\Delta 36$ mice (Fig. $5 A, B$ ). In these experiments, response ratios were $3.42 \pm 0.88(n=40$ cells $/ 10$ animals $)$ and $4.38 \pm 1.61(n=64$ cells $/ 10$ animals $)$ for DRG neurons from WT and $\Delta 36$ mice, respectively ( $p=0.66$, unpaired Student's $t$ test). Also, some DRG neurons from WT mice ( 4 of 121 neurons, 10 animals) and $\Delta 36$ mice (14 of 169 neurons, 10 animals) that initially failed to respond to $100 \mathrm{~nm}$ capsaicin exhibited a large capsaicin-induced $\left[\mathrm{Ca}^{2+}\right]_{\mathrm{i}}$ transient after pre- 

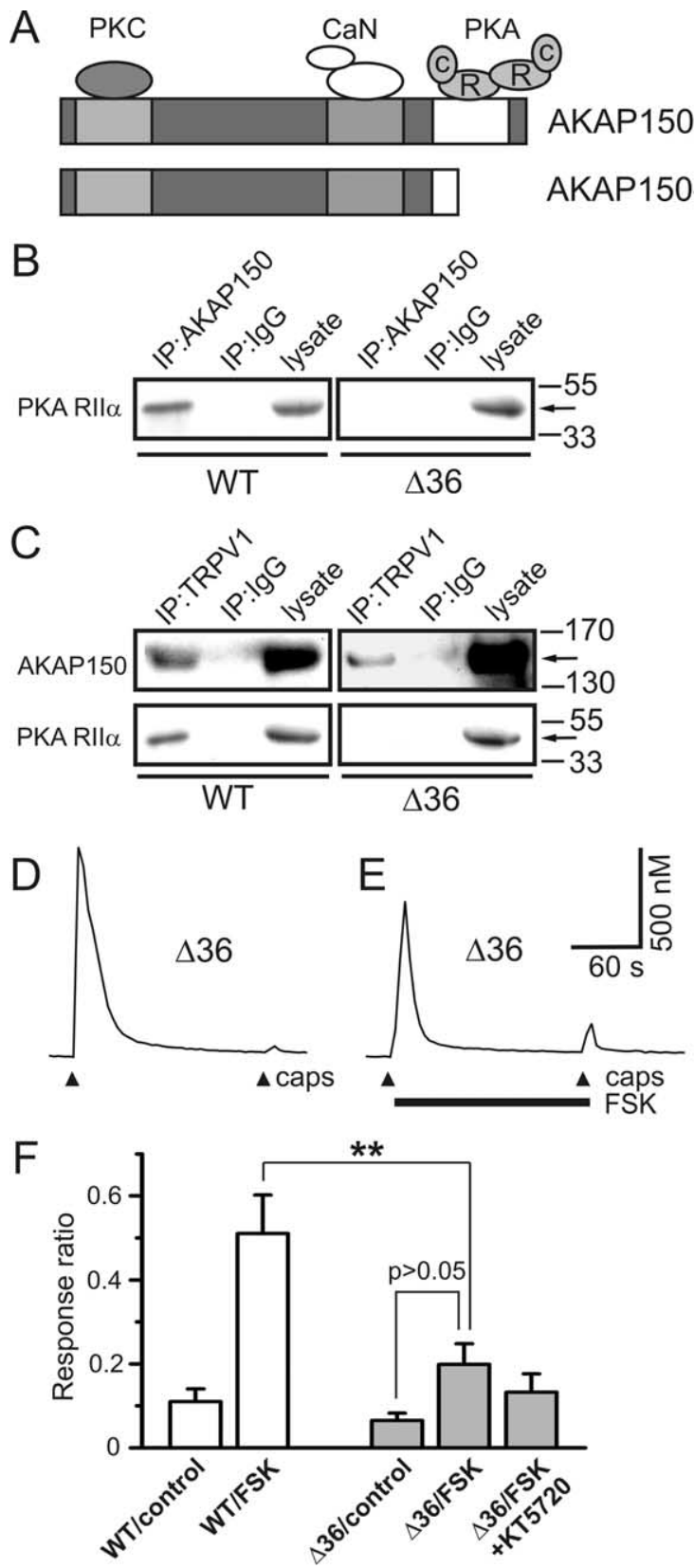

Figure 4. Disruption of PKA binding to AKAP150 inhibits TRPV1 modulation by forskolin. $\boldsymbol{A}$, Diagram shows primary structure of AKAP150 with binding sites for PKC, calcineurin (CaN), and PKA (modified from Dell'Acqua et al., 2006). In the truncated version of AKAP150 (AKAP150$\Delta 36$ ), the last 36 amino acids of the (terminus are removed to disrupt PKA binding. B, PKA RIl $\alpha$ associates with AKAP150 in WT but not in $\triangle 36$ mice. AKAP150 was immunoprecipitated from Triton X-100 solubilized spinal cord membranes with an anti-AKAP150 antibody, and immunoprecipitates were analyzed by immunoblotting with an antibody against PKA RIl $\alpha$ (4 independent experiments, 24 animals from each strain). C, PKA RIl $\alpha$ coimmunoprecipitates with TRPV1 from adult mouse spinal cord in WT but not AKAP150- $\Delta 36$ mice. Immunoprecipitations were performed with an antibody against TRPV1 or nonimmune control antibodies, separated by SDS-PAGE, and probed with antibodies against AKAP150 and the regulatory subunit of PKA RIll $\alpha$ (5 independent experiments, 27 animals from each strain). D, E, $\left[\mathrm{Ca}^{2+}\right]_{i}$ elevations elicited by two stimulations with capsaicin (100 nm for $10 \mathrm{~s}, 3$ min between the stimulations indicated by arrowheads) were recorded in DRG neurons from $\Delta 36$ mice. Between capsaicin applications, cells were superfused with either control $\mathrm{HH}$ buffer (D) or HH buffer containing 10 $\mu \mathrm{m}$ forskolin (FSK, horizontal bar) (E). $\boldsymbol{F}$, Bar graph shows that the ability of forskolin to reduce TRPV1 desensitization was significantly impaired in DRG neurons from $\Delta 36$ mice. Response ratios were obtained from experiments such as those shown in $\boldsymbol{D}$ and $\boldsymbol{E}$ and are presented as mean \pm SEM. For comparison between DRG neurons from WT (white bars) and $\Delta 36$ (gray bars) mice, data for WT/control and WT/forskolin conditions were replotted from Figure $3 G .{ }^{* *} p<$ 0.01 , one-way ANOVA with Bonferroni's post hoc test.
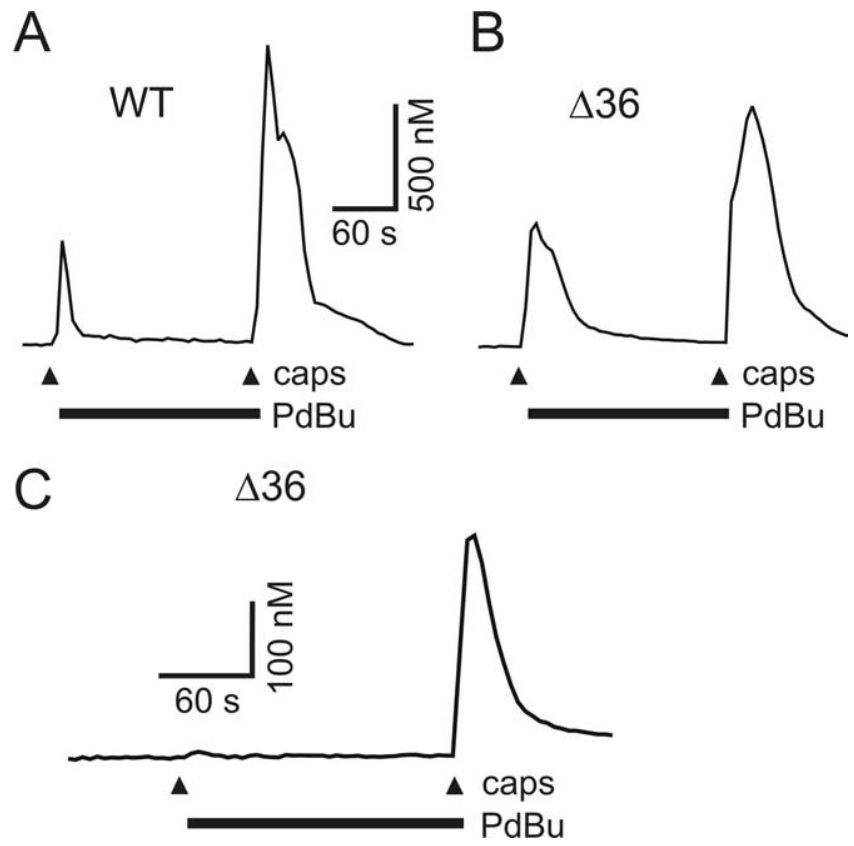

Figure 5. Sensitization of TRPV1 via PKC is not impaired in DRG neurons from $\Delta 36$ mice. $A$, $\boldsymbol{B},\left[\mathrm{Ca}^{2+}\right]_{\mathrm{i}}$ responses in DRG neurons from WT mice $(\boldsymbol{A})$ and $\Delta 36$ mice $(\boldsymbol{B})$ were evoked by two applications of capsaicin (arrowheads; $100 \mathrm{~nm}$ for $10 \mathrm{~s}, 3 \mathrm{~min}$ apart). Cells were superfused with $500 \mathrm{~nm} \mathrm{PdBu}$ (horizontal bar) between the capsaicin applications to induce PKC activation. $C$, $\left[\mathrm{Ca}^{2+}\right]_{\mathrm{i}}$ recording in a DRG neuron ( $\Delta 36$ mice) that did not initially respond to $100 \mathrm{~nm}$ capsaicin (10s) application but became responsive to capsaicin after PKC stimulation. Similar sensitizing effects of PdBu on capsaicin-induced $\left[\mathrm{Ca}^{2+}\right]_{i}$ changes were observed in 4 of $121 \mathrm{DRG}$ neurons from WT mice and in 14 of 169 DRG neurons from $\Delta 36$ mice.

treatment with $\mathrm{PdBu}$ (Fig. 5C). Overall, these data show that PKC-dependent modulation of TRPV1 is not affected in $\Delta 36$ mice.

PKA anchoring by AKAP150 is important for PGE $_{2}-$ dependent modulation of TRPV1

$\mathrm{PGE}_{2}$ is an important inflammatory mediator, and $\mathrm{PGE}_{2}$ levels are increased at the periphery and in the CNS after tissue injury or inflammation (Svensson and Yaksh, 2002; Park and Vasko,

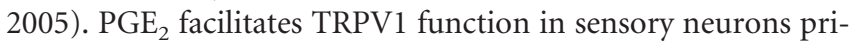
marily via PKA-dependent phosphorylation of the receptor (Lopshire and Nicol, 1998; Southall and Vasko, 2001; Hu et al., 2002; Gu et al., 2003), although a recent study suggests that PKC is also involved (Moriyama et al., 2005). Using the 3 min pairedpulse protocol, we investigated the effect of $\mathrm{PGE}_{2}$ on capsaicininduced $\left[\mathrm{Ca}^{2+}\right]_{\mathrm{i}}$ changes in DRG neurons from WT and $\Delta 36$ mice. As shown in Figure 6, treatment with $5 \mu \mathrm{M} \mathrm{PGE}_{2}$ markedly reduced TRPV1 desensitization in DRG neurons from WT mice, leading to a significant enhancement of the $\left[\mathrm{Ca}^{2+}\right]_{\mathrm{i}}$ response to the second capsaicin application and yielding a response ratio of $0.75 \pm 0.17$ ( $n=31$ cells $/ 8$ animals $)$. The effect of $\mathrm{PGE}_{2}$ on TRPV1 desensitization was significantly diminished in DRG neurons from $\Delta 36$ mice (Fig. $6 B, E$ ), giving a response ratio of only $0.35 \pm 0.09$ ( $n=33$ cells $/ 6$ animals). In DRG neurons from both

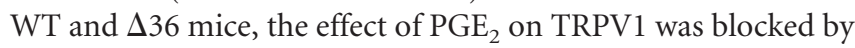
pretreatment with $1 \mu \mathrm{M}$ KT5720 (WT: response ratio, $0.17 \pm$ $0.04, n=24$ cells $/ 2$ animals; $\Delta 36$ : response ratio, $0.17 \pm 0.06, n=$ 37 cells/4 animals) (Fig. 6C-E).

$\mathrm{Ca}^{2+}$ imaging provides a powerful tool for studying $\mathrm{Ca}^{2+}$ entry in a mixed population of cells, e.g., capsaicin-responding and nonresponding DRG neurons. However, the amplitude of 

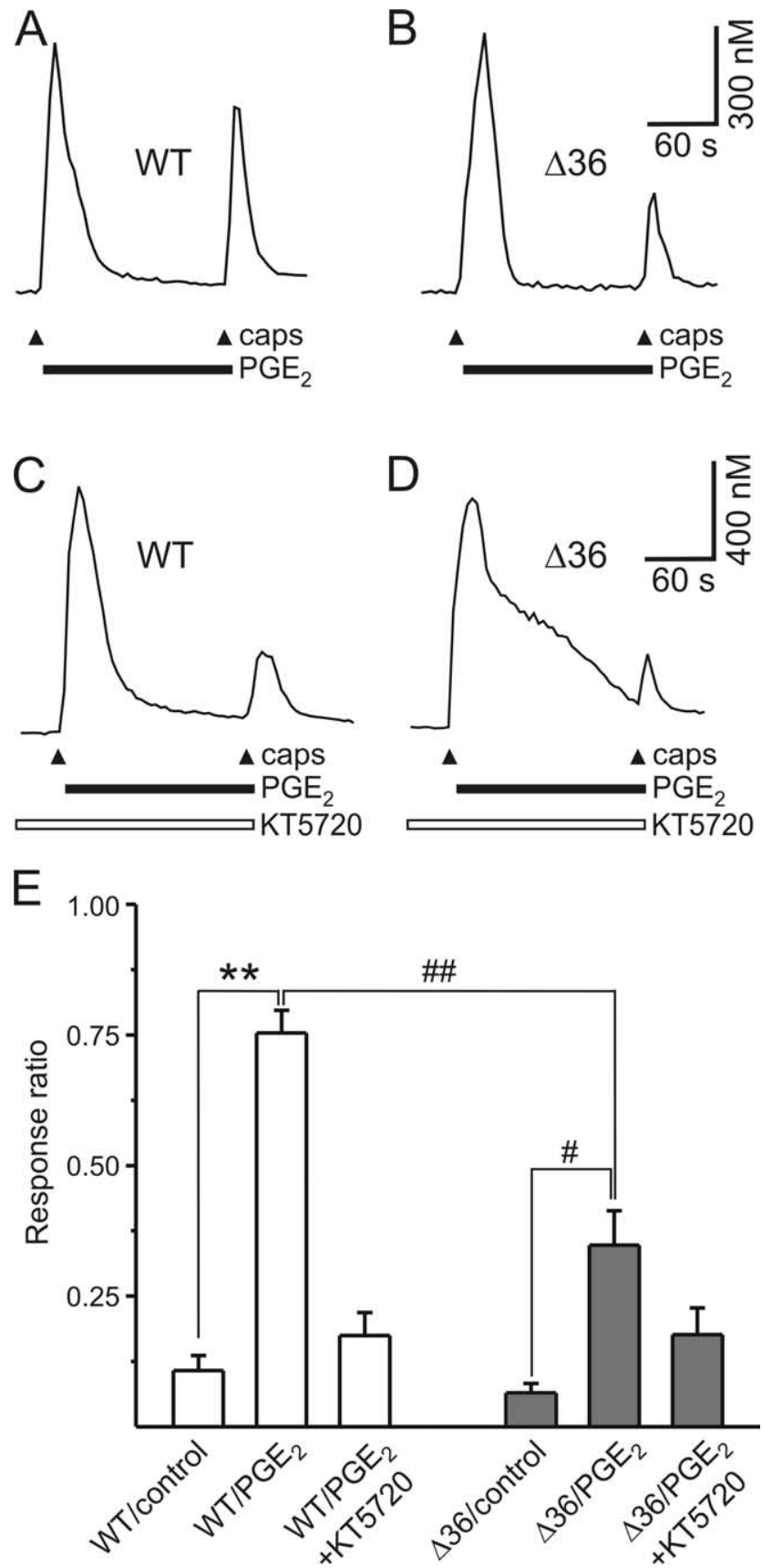

Figure 6. PGE reduces desensitization of TRPV1 via AKAP150-anchored PKA. $\boldsymbol{A}-\boldsymbol{D}$, Representative $\left[\mathrm{Ca}^{2+}\right]_{\mathrm{i}}$ responses evoked by two applications of capsaicin (arrowheads; $100 \mathrm{~nm}$ for $10 \mathrm{~s}, 3$ min apart) in DRG neurons treated with $5 \mu \mathrm{M} \mathrm{PGE}_{2}$ alone $(\boldsymbol{A}, \boldsymbol{B})$ or with $5 \mu \mathrm{M} \mathrm{PGE}_{2}$ and 1 $\mu \mathrm{M} K 5720(\boldsymbol{C}, \boldsymbol{D}) .\left[\mathrm{Ca}^{2+}\right]_{\mathrm{i}}$ changes are compared between DRG neurons from WT mice $(\boldsymbol{A}, \boldsymbol{C})$ and those from $\Delta 36$ mice $(\boldsymbol{B}, \boldsymbol{D})$. Applications of $\mathrm{PGE}_{2}$ (horizontal black bar) and KT5720 (horizontal white bar) are shown under the traces. Incubation with $1 \mu \mathrm{m}$ KT5720 started 20 min before the first capsaicin application. $\boldsymbol{E}$, Bar graph summarizes the effects of PGE ${ }_{2}$ and KT5720 on TRPV1-mediated $\left[\mathrm{Ca}^{2+}\right]_{\mathrm{i}}$ responses in DRG neurons from WT (white bars) and $\Delta 36$ (gray bars) mice. Data were obtained from experiments such as those shown in $\boldsymbol{A}-\boldsymbol{D}$ and are presented as mean \pm SEM. Data for WT/control and $\Delta 36 /$ control were replotted from Figures $3 G$ and 4 , respectively, to enable comparison of the $P G E_{2}$ effects in both strains of animals. ${ }^{* *} p<$ 0.01 , relative to $\mathrm{WT} /$ control; $\# p<0.05$ and ${ }^{\# \#} p<0.01$ relative to $\Delta 36 / \mathrm{PGE}_{2}$; one-way ANOVA with Bonferroni's post hoc test.

the $\left[\mathrm{Ca}^{2+}\right]_{\mathrm{i}}$ response can also be affected by the $\mathrm{Ca}^{2+}$ buffering processes. Therefore, we further examined the effects of $\mathrm{PGE}_{2}$ by monitoring TRPV1-mediated currents directly, using patchclamp (Fig. 7). In these patch-clamp experiments, whole-cell cur-
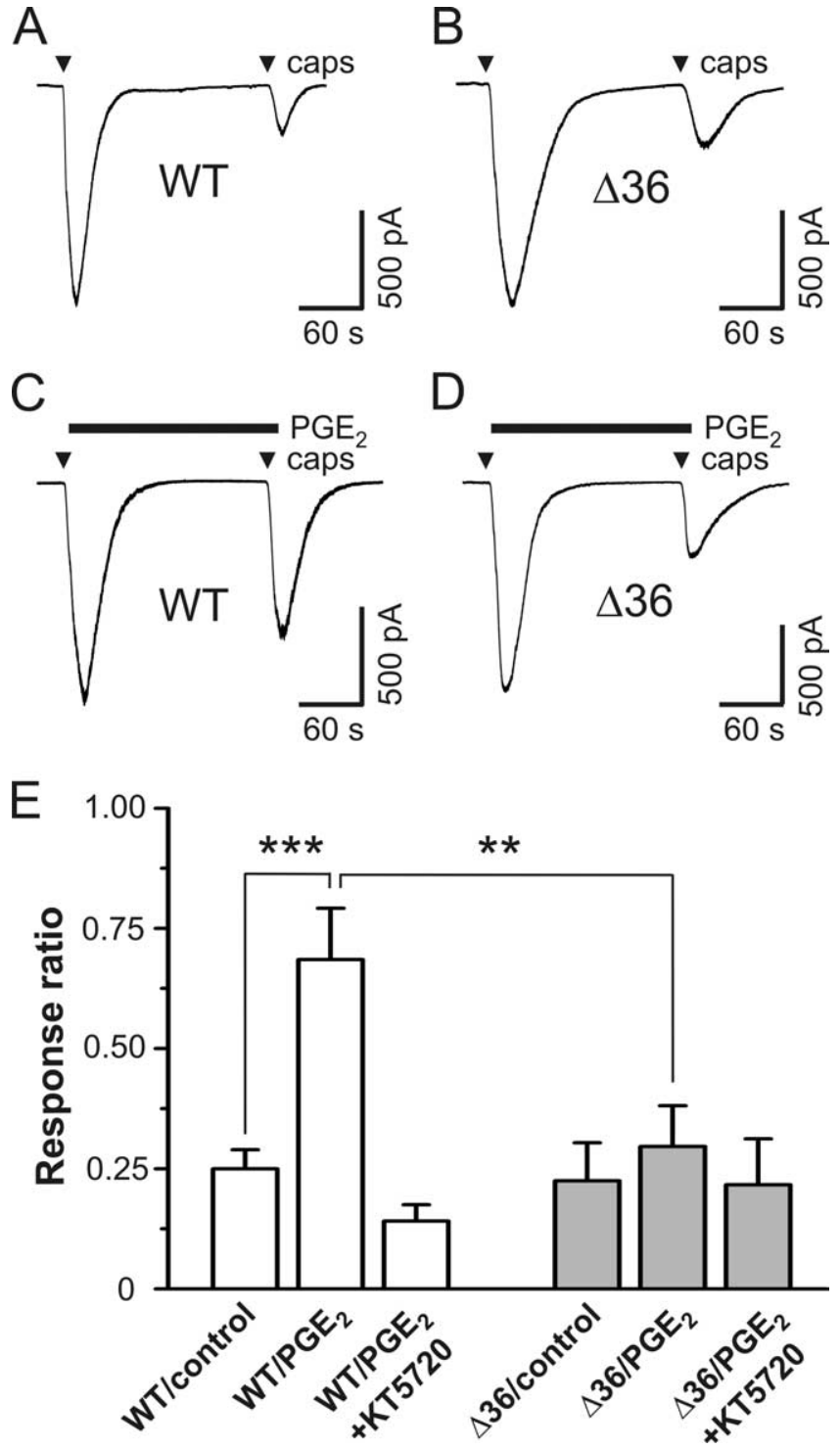

Figure 7. $P G E_{2}$ reduces desensitization of capsaicin-evoked currents in DRG neurons from WT but not from $\Delta 36$ mice. $A-D$, Representative patch-clamp recordings $\left(V_{\text {hold }}\right.$ of $\left.-60 \mathrm{mV}\right)$ of capsaicin-induced $(1 \mu \mathrm{m}, 10 \mathrm{~s})$ currents from WT $(\boldsymbol{A}, \boldsymbol{C})$ and $\Delta 36(\boldsymbol{B}, \boldsymbol{D})$ DRG neurons that were exposed to the control solution $(\boldsymbol{A}, \boldsymbol{B})$ or solution containing $5 \mu \mathrm{M} \mathrm{PGE}_{2}(\boldsymbol{C}, \boldsymbol{D}$; black bars) between two capsaicin applications. $\boldsymbol{E}$, Bar graph quantifies reduction of desensitization of capsaicin-evoked currents by PGE and the effect of the PKA inhibitor KT5720 (1 $\mu \mathrm{M})$ in DRG neurons from WT and $\Delta 36$ mice. Data were obtained from experiments like those described in $\boldsymbol{A}-\boldsymbol{D}$. Cells were incubated with KT5720 for 3 min before the first capsaicin exposure. ${ }^{* *} p<$ $0.01,{ }^{* * *} p<0.001$, one-way ANOVA with Bonferroni's post hoc test.

rents were evoked by two applications of capsaicin ( $1 \mu \mathrm{M}, 10 \mathrm{~s})$ that were separated by $3 \mathrm{~min}$. Capsaicin-induced currents strongly desensitized under control conditions, giving a response ratio (current amplitude $_{2} /$ current $_{\text {amplitude }}$ ) of $0.25 \pm 0.04$ ( $n=10$ cells $/ 5$ animals $)$ and $0.22 \pm 0.08(n=6$ cells $/ 4$ animals $)$ in WT and $\Delta 36$ DRG neurons, respectively. The desensitization was significantly reduced by the addition of $5 \mu \mathrm{M} \mathrm{PGE}_{2}$ to DRG neurons from WT (response ratio, $0.69 \pm 0.11 ; n=7$ cells $/ 4$ animals) but not $\Delta 36$ mice (response ratio, $0.29 \pm 0.09 ; n=5$ cells $/ 4$ animals). Pretreating the cells with the PKA inhibitor KT5720 blocked the effect of $\mathrm{PGE}_{2}$ (Fig. $7 E$ ). In this latter case, the response ratio was $0.14 \pm 0.03$ for WT DRG neurons $(n=5$ cells $/ 3$ animals) and $0.22 \pm 0.10$ for DRG neurons from $\Delta 36$ mice $(n=$ 4 cells/3 animals). 
Overall, the described $\left[\mathrm{Ca}^{2+}\right]_{\mathrm{i}}$ imaging and patch-clamp data demonstrate that $\mathrm{PGE}_{2}$-induced modulation of TRPV1 in sensory neurons is mediated by AKAP150anchored PKA.

\section{Expression of full-length AKAP79} rescues $\mathrm{PGE}_{2}$-dependent modulation of TRPV1 in $\Delta \mathbf{3 6}$ mice

Defective TRPV1 regulation in $\Delta 36$ mice could be an indirect consequence of disrupted PKA signaling in these knock-in animals. We therefore examined whether the deficiency in $\mathrm{PGE}_{2} / \mathrm{PKA}$-dependent enhancement of TRPV1 function in $\Delta 36$ mouse DRG neurons could be acutely rescued by expressing the full-length human ortholog of AKAP150, AKAP79. This protein shares a high degree of homology and functional similarity with AKAP150 (Carr et al., 1992; Wong and Scott, 2004; Dell'Acqua et al., 2006). The effect of AKAP79 was also compared with those of several other AKAPs characterized by distinct functions and subcellular localizations, including D-AKAP1, D-AKAP2, AKAP15/18, and AKAP250 (Nauert et al., 1997; Fraser et al., 1998; Tibbs et al., 1998; Huang et al., 1999; Trotter et al., 1999; Wang et al., 2001). To this end, we transfected DRG neurons with either EYFP- or EGFP-tagged AKAP constructs or with EYFP alone using the Amaxa Biosystems electroporation system. EYFP distributed evenly throughout the cytoplasm (image in Fig. $8 A$ ), whereas AKAP79-EYFP and AKAP15/18-EGFP were concentrated at the cell periphery (images in Fig. $8 B, D$ ) and the mitochondria-associated D-AKAP2 was distributed throughout the cell body excluding the nucleus (image in Fig. 8C). The distribution of D-AKAP1 (data not shown) was similar to that of D-AKAP2, whereas AKAP250 was found both at the plasma membrane and in the cytosol (data not shown). Under control conditions, the TRPV1mediated response in EYFP-transfected DRG neurons from WT mice was strongly desensitized after stimulation with capsaicin (response ratio, $0.03 \pm$ $0.02 ; n=21$ cells $/ 15$ animals). Treatment with $\mathrm{PGE}_{2}$ dramatically reduced TRPV1 desensitization in DRG neurons from WT mice (response ratio, $0.31 \pm$ $0.05 ; n=47$ cells $/ 15$ animals). The effect of $\mathrm{PGE}_{2}$ was strongly diminished in EYFP-transfected DRG neurons from $\Delta 36$ mice (response ratio, $0.11 \pm 0.04$; $n=31$ cells $/ 7$ animals) (Fig. $8 A$ ). The expression of AKAP79-EYFP, but not of any other examined AKAP, restored the $\mathrm{PGE}_{2}$ effect in DRG neurons from $\Delta 36$
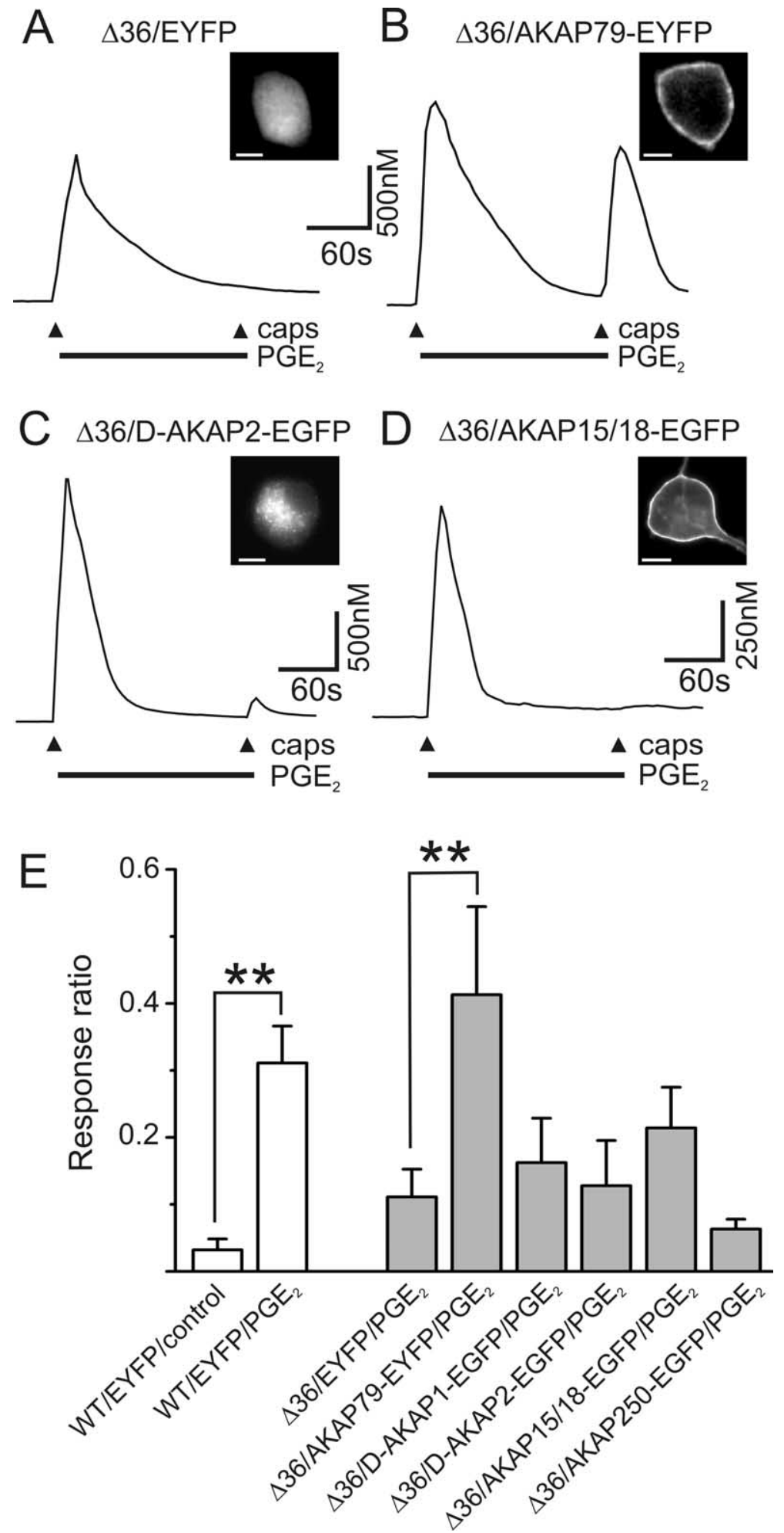

Figure 8. AKAP79 rescues the $P G E_{2}$ effect in DRG neurons from $\Delta 36$ mice. $A-D, D R G$ neurons from $\Delta 36$ mice were transfected with $\operatorname{EYFP}(\boldsymbol{A})$, AKAP79 - EYFP $(\boldsymbol{B})$, D-AKAP2-EGFP $(\boldsymbol{C})$, or AKAP15/18 -EGFP $(\boldsymbol{D})$. Images show fluorescence distribution in transfected neurons ( $\lambda_{\mathrm{ex}}=475 \mathrm{~nm}, \lambda_{\mathrm{em}}=530 \mathrm{~nm}$; scale bars, $10 \mu \mathrm{m}$ ). Transfected DRG neurons were loaded with fura-2 and $\left[\mathrm{Ca}^{2+}\right]_{\mathrm{i}}$ transients were evoked by two subsequent applications of capsaicin (arrowheads; $100 \mathrm{~nm}$ for $10 \mathrm{~s}, 3 \mathrm{~min}$ apart). Treatments with $5 \mu \mathrm{M}$ PGE 2 are indicated by horizontal bars under the traces. $\boldsymbol{E}$, Bar graph summarizes the effects of PGE ${ }_{2}$ on TRPV1 in DRG neurons from WT and $\Delta 36$ micetransfected with either EYFP or plasmids encoding different AKAPs. Data were obtained from experiments such as those shown in $\boldsymbol{A}-\boldsymbol{D}$ and are presented as mean \pm SEM. The bars represent 21 cells/15 animals for WT/EYFP/control, 47 cells/15

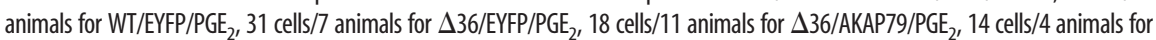
$\Delta 36 / \mathrm{D}-\mathrm{AKAP} 1 / \mathrm{PGE}_{2}, 9$ cells/6 animals for $\Delta 36 / \mathrm{D}-\mathrm{AKAP}_{2} / \mathrm{PGE}_{2}, 21$ cells/10 animals for $\Delta 36 / \mathrm{AKAP} 15 / 18 / \mathrm{PGE}_{2}$, and 9 cells $/ 5$ animals for $\Delta 36 /$ AKAP250/PGE $_{2}{ }^{* *} p<0.01$, one-way ANOVA with Bonferroni's post hoc test. 
A
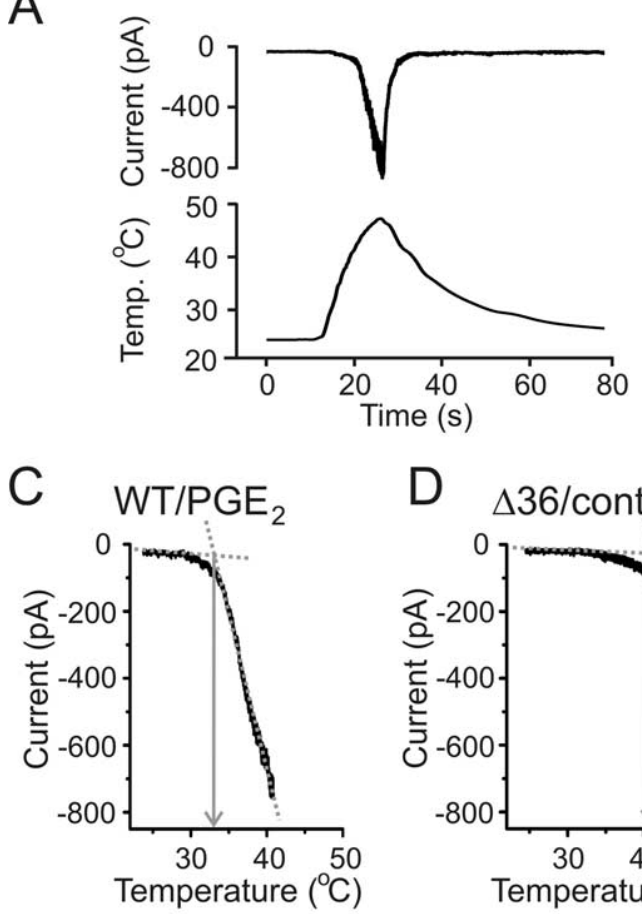

D $\Delta 36 /$ control

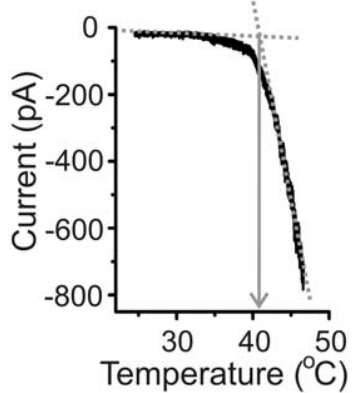

$\mathrm{F}$
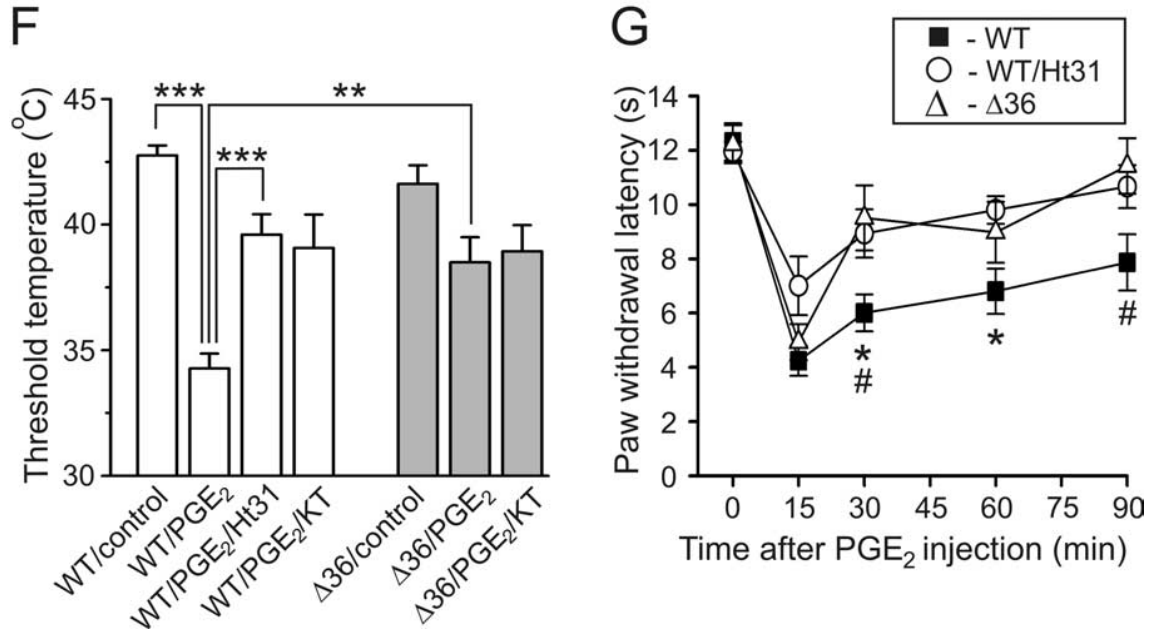

Figure 9. $P G E_{2}$-induced enhancement of thermal sensitivity is impaired in $\Delta 36$ mice. $A$, Representative recording of heatactivated currents (top trace) induced by a transient increase of extracellular temperature (bottom trace). This specific recording was obtained from a WT DRG neuron voltage clamped at $-60 \mathrm{mV}$ (also shown in $\boldsymbol{B}$ ). $\boldsymbol{B}-\boldsymbol{E}$, Heat-activated currents were induced as described in $A$ and plotted as a function of extracellular temperature for DRG neurons from WT $(\boldsymbol{B}, \boldsymbol{C})$ and $\Delta 36$ mice $(\boldsymbol{D}, \boldsymbol{E})$ under control conditions $(\boldsymbol{B}, \boldsymbol{D})$ or in the presence of $5 \mu \mathrm{M} \mathrm{PGE}_{2}(3$ min pretreatment; $\boldsymbol{C}, \boldsymbol{E})$. Gray vertical arrows indicate threshold temperature for each plot, which was defined as the intersection between the lines (gray dotted lines) approximating the baseline and the clearly increasing temperature-dependent inward current (Sugiura et al., 2002, 2004).F, Bar graph summarizes temperature thresholds of heat-activated currents in DRG neurons from WT (white bars) and $\Delta 36$ (gray bars) mice, recorded

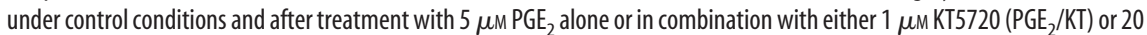
$\mu \mathrm{M} \mathrm{Ht} 31$ (PGE $/ / \mathrm{Ht}$ ). Ht31 was included in the pipette solution, and KT5720 was applied for 6 min before the recordings. ${ }^{* *} p<$ $0.01,{ }^{* * *} p<0.001$, ANOVA with Bonferroni's post hoc test. G, PGE 2 -induced thermal hyperalgesia was studied in WT and $\Delta 36$ mice. PGE 2 was injected into plantar surface of the hindpaw ( $100 \mathrm{ng}$ in $10 \mu$ l) of WT ( $n=16$; square) or $\Delta 36$ ( $n=11$; triangle) mice or a mixture of $\mathrm{PGE}_{2}$ plus $\mathrm{Ht} 31(100 \mathrm{ng}+8 \mu \mathrm{g}$ in $10 \mu \mathrm{l})$ was injected into plantar surface of a WT mouse hindpaw $(n=15$; circle). Paw-withdrawal latency to radiant heat was measured at various times after the injection. The baseline latency for each group (time $=0 \mathrm{~min}$ ) was determined before the injection by averaging the results of three tests separated by a 5 min interval. ${ }^{*} p<0.05$, relative to WT/Ht31; ${ }^{*} p<0.05$, relative to $\triangle 36$; ANOVA with Bonferroni's post hoc test.

mice (Fig. $8 B-E)$, yielding a response ratio of $0.41 \pm 0.14(n=$ 18 cells/ 11 animals). Thus, AKAP79 rescues the $\Delta 36$ deficit in $\mathrm{PGE}_{2}$-dependent modulation of TRPV1.
$\mathrm{PGE}_{2}$-induced thermal hypersensitivity is diminished in $\mathbf{\Delta} \mathbf{3 6}$ mice

Under physiological conditions, TRPV1 is activated by heat above $42-43^{\circ} \mathrm{C}$ (Caterina et al., 1997; Tominaga et al., 1998). Phosphorylation-dependent lowering of TRPV1 thermal activation threshold by inflammatory mediators is likely one of the key mechanisms contributing to thermal hyperalgesia after tissue injury or inflammation (Bhave and Gereau, 2004; Nagy et al., 2004; Immke and Gavva, 2006). Accordingly, disruption of the TRPV1 gene or pharmacologic inhibition of TRPV1 strongly diminish inflammatory thermal hypersensitivity (Caterina et al., 2000; Davis et al., 2000; Gavva et al., 2005; Cui et al., 2006). In particular, it has been shown that $\mathrm{PGE}_{2}$-induced thermal hyperalgesia is essentially eliminated in TRPV1 knock-out mice (Moriyama et al., 2005). Given the marked deficit of TRPV1 modulation by $\mathrm{PGE}_{2}$ in $\Delta 36$ mice (Figs. 6,7 ), it is conceivable that $\mathrm{PGE}_{2}$-induced enhancement of thermal sensitivity is also impaired in these mice. To test this idea, we first compared the effects of $\mathrm{PGE}_{2}$ on heat-activated currents in capsaicin-sensitive DRG neurons from WT and $\Delta 36$ mice. Capsaicin sensitivity was determined by $\left[\mathrm{Ca}^{2+}\right]_{\mathrm{i}}$ imaging, as described above. Specifically, cells in which capsaicin application (100 nM, $10 \mathrm{~s})$ induced a $\left[\mathrm{Ca}^{2+}\right]_{\mathrm{i}}$ elevation that was at least $100 \%$ higher than the resting $\left[\mathrm{Ca}^{2+}\right]_{\mathrm{i}}$ and reached $150 \mathrm{~nm}$ were chosen. Cells were washed of capsaicin for at least $1 \mathrm{~h}$ to enable a full recovery of TRPV1 from desensitization (Fig. 2). Heat-activated currents were induced by applying temperature ramps (Fig. 9A) and were plotted as a function of extracellular temperature for additional analysis (Fig. 9B-E), similar to the approach described by other groups (Sugiura et al., 2002, 2004; Moriyama et al., 2005). Under control conditions, heat-activated currents in DRG neurons from WT and $\Delta 36$ mice showed similar threshold temperatures (WT: $42.8 \pm 0.4^{\circ} \mathrm{C}, n=8$ cells $/ 5$ animals; $\Delta 36: 41.6 \pm 0.7^{\circ} \mathrm{C}, n=8$ cells $/ 4$ animals). These values are in good agreement with the temperature requirement for TRPV1 activation (Tominaga et al., 1998; Sugiura et al., 2002; Kim et al., 2006), as well as with the thermal response thresholds reported for heat-activated currents in sensory neurons by others (Caterina et al., 2000; Davis et al., 2000; Rathee et al., 2002). Exposure of cells to $\mathrm{PGE}_{2}(5 \mu \mathrm{M})$ produced a marked leftward shift in the temperature dependence of heat-activated currents in WT DRG neurons (temperature threshold, $34.3 \pm 0.6^{\circ} \mathrm{C} ; n=12$ cells/5 animals) (Fig. 9C). This $\mathrm{PGE}_{2}$-induced temperature shift was significantly reduced in DRG neurons from $\Delta 36$ mice 
$\left(38.5 \pm 0.9^{\circ} \mathrm{C} ; n=8\right.$ cells $/ 4$ animals) (Fig. $\left.9 E\right)$. It was also reduced in WT DRG neurons by pretreatment with the AKAP inhibitory peptide $\mathrm{Ht} 31$ (temperature threshold, $39.6 \pm 0.8^{\circ} \mathrm{C} ; n=5$ cells $/ 3$ animals). The PKA inhibitor KT5720 also blocked the $\mathrm{PGE}_{2}$ effect in WT DRG neurons (temperature threshold, $39.1 \pm 1.3^{\circ} \mathrm{C} ; n=$ 7 cells/3 animals; $p<0.001$ ), whereas an already small $\mathrm{PGE}_{2^{-}}$ induced temperature shift in $\Delta 36$ DRG neurons was not further reduced by KT5720 (Fig. 9F) (temperature threshold, $38.9 \pm$ $1.0^{\circ} \mathrm{C} ; n=8$ cells $/ 3$ animals; $\left.p>0.05\right)$.

We further tested the role of AKAP150 in regulating thermal sensitivity by studying paw-withdrawal latency in response to a radiant heat stimulus (Hargreaves et al., 1988) in WT and $\Delta 36$ mice. Both strains of mice showed similar paw-withdrawal latencies under the basal conditions (Fig. 9G, time =0). These results are in agreement with the findings that heat-activated currents in DRG neurons from WT and $\Delta 36$ had a similar threshold temperature under control conditions (Fig. $9 F)$. Injection of $\mathrm{PGE}_{2}(100$ $\mathrm{ng} / 10 \mu \mathrm{l})$ into the plantar surface of the hindpaw induced thermal hyperalgesia that lasted for $>1 \mathrm{~h}$. The magnitude and the time course of the $\mathrm{PGE}_{2}$ effect were consistent with those reported by other groups (Malmberg et al., 1997; Yang and Gereau, 2002; Moriyama et al., 2005). Examination of $\Delta 36$ mice showed that $\mathrm{PGE}_{2}$-induced hyperalgesia was significantly diminished in these animals (Fig. 9G). Furthermore, coadministration of the membrane-permeable AKAP inhibitory peptide $\mathrm{Ht} 31$ to the hindpaw of WT mice also significantly decreased the $\mathrm{PGE}_{2}$ effect.

Overall, the described behavioral data are in good agreement with the patch-clamp results and suggest that the $\mathrm{PGE}_{2}$-induced reduction of the heat-activated current temperature threshold is one of the key mechanisms contributing to thermal hyperalgesia in response to $\mathrm{PGE}_{2}$ injection. Our data also suggest that the development of $\mathrm{PGE}_{2}$-induced thermal hyperalgesia critically depends on AKAP150-anchored PKA.

\section{Discussion}

This study demonstrates that PKA anchoring by AKAP150 is essential for the $\mathrm{PGE}_{2} / \mathrm{PKA}$-dependent modulation of TRPV1 in mouse sensory neurons. Several lines of evidence support this conclusion. First, TRPV1 and AKAP150 are coexpressed in DRG neurons and coimmunoprecipitate. This coimmunoprecipitation indicates that AKAP150 and TRPV1 are in close proximity to each other, perhaps interacting with each other. Second, the disruption of PKA binding by the AKAP150 mutant in $\Delta 36$ mice strongly diminished $\mathrm{PGE}_{2} / \mathrm{PKA}$-dependent modulation of TRPV1. Overexpression of the full-length human ortholog of AKAP150, but not of other AKAPs, completely restored the ability of $\mathrm{PGE}_{2}$ to enhance TRPV1 function in DRG neurons from $\Delta 36$ mice. Finally, $\mathrm{PGE}_{2}$-induced thermal hypersensitivity was significantly diminished in $\Delta 36$ mice. Phosphorylationdependent modulation of TRPV1 by inflammatory mediators is an important mechanism contributing to sensitization of nociceptors (Julius and Basbaum, 2001; Bhave and Gereau, 2004), and our work establishes AKAP150 as a critical molecular component of the cellular machinery that controls this process.

The AKAP inhibitory peptide Ht31 has been shown previously to prevent potentiation of heat- and proton-activated currents by forskolin and serotonin, respectively (Rathee et al., 2002; Sugiura et al., 2004). We found that Ht31 also blocked the effect of forskolin on TRPV1 function in our system (Fig. 3E). By competing with endogenous AKAPs for binding to PKA regulatory subunits, Ht31 displaces the PKA holoenzyme from its cellular substrates (Hundsrucker et al., 2006). Although previous studies using Ht31 have helped to establish the importance of PKA an- choring for TRPV1 regulation, they have not answered the question of which AKAP mediates this regulation. The AKAP family comprises $>50$ proteins that differ in their signaling function and tissue distribution (Wong and Scott, 2004), and at least four AKAPs, including AKAP15/18, AKAP150, AKAP250, and Yotiao, are expressed in DRG (Fig. $1 A$ ). In this work, we provide evidence for the crucial role of AKAP150 in directing PKA activity at TRPV1 in sensory neurons.

AKAP150 is expressed in the majority of TRPV1-positive DRG neurons and is highly concentrated at the plasma membrane (Fig. 1D). Moreover, AKAP79-EYFP concentrated near the plasma membrane when it was overexpressed in DRG neurons (Fig. $8 \mathrm{~B}$ ). TRPV1 is also present at the plasma membrane but, overall, shows a more widespread distribution throughout the cell body (Fig. 1D). Other groups have reported similar TRPV1 distribution in rodent DRG neurons both in vivo and in vitro (Guo et al., 1999; Rathee et al., 2002; Zwick et al., 2002; Liu et al., 2003; Malin et al., 2006). It is likely that intracellular TRPV1 immunofluorescence reflects an association of the receptor with the endoplasmic reticulum and Golgi complex (Guo et al., 1999; Liu et al., 2003; Karai et al., 2004). In all DRG neurons that expressed both TRPV1 and AKAP150, these proteins colocalized near the plasma membrane. More convincing evidence for association of these proteins was obtained by showing that AKAP150, but not AKAP15/18, AKAP250, or Yotiao, coimmunoprecipitates with TRPV1 from DRG and spinal cord (Fig. $1 B$ ). Moreover, PKA RII $\alpha$ is associated with TRPV1 in WT but not in $\Delta 36$ mice (Fig. 4C). Combined, our data imply a signaling complex containing TRPV1, AKAP150, and PKA (Fig. 4C). Whether AKAP150 and TRPV1 interact directly or via membraneassociated scaffold proteins, such as the membrane-associated guanylate kinase family proteins (Colledge et al., 2000), remains to be investigated.

To evaluate the function of AKAP150 in DRG neurons, we compared PKA-dependent modulation of TRPV1 in DRG neurons from WT mice and from mice expressing a mutated form of AKAP150 that lacks the PKA binding domain ( $\Delta 36$ mice). TRPV1 phosphorylation by PKA can both sensitize the receptor (Lopshire and Nicol, 1998; Rathee et al., 2002) and decrease TRPV1 desensitization (Bhave et al., 2002; Mohapatra and Nau, 2003), depending on the amino acid residue at which phosphorylation occurs (Mohapatra and Nau, 2005). We found that stimulation of PKA with forskolin dramatically reduced TRPV1 desensitization in DRG neurons from WT mice but not in those from $\Delta 36$ mice. Similarly, the ability of $\mathrm{PGE}_{2}$ to prevent TRPV1 desensitization, and therefore to enhance receptor function during repeated stimulation, was strongly diminished in DRG neurons from $\Delta 36$ mice. Furthermore, we found that the threshold temperature of heat-activated currents was markedly $\left(\sim 8^{\circ} \mathrm{C}\right)$ reduced by $\mathrm{PGE}_{2}$ and that this effect, as well as $\mathrm{PGE}_{2}$-induced thermal hyperalgesia, was significantly diminished in $\Delta 36$ mice. These findings have several implications. First and most importantly, they support our hypothesis that PKA anchoring via AKAP150 is essential for mediating $\mathrm{PGE}_{2}$-induced modulation of TRPV1. This idea was corroborated by our rescue experiments, in which reintroduction of the AKAP79/150 PKA-binding site reconstituted the full $\mathrm{PGE}_{2}$ effect on TRPV1 in DRG neurons from $\Delta 36$ mice. Second, they show that the cAMP/PKA pathway is a major signaling cascade that mediates TRPV1 modulation by $\mathrm{PGE}_{2}$ in DRG neurons. This is in good agreement with findings by others that $\mathrm{PGE}_{2}$ exerts its effects on sensory neurons via $\mathrm{EP} 3 \mathrm{C}$ and $\mathrm{EP} 4$ receptors, which are coupled through $\mathrm{G}_{\mathrm{s}}$ proteins to the activation of the cAMP/PKA signaling cascade (Hingtgen et al., 
1995; Lopshire and Nicol, 1998; Southall and Vasko, 2001; Gu et al., 2003; Lin et al., 2006). The residual effect of $\mathrm{PGE}_{2}$ on TRPV1 in DRG neurons from $\Delta 36$ mice could potentially be mediated by $\mathrm{PGE}_{2}$ receptor subtypes that are coupled to the PKC-dependent pathway (Moriyama et al., 2005), which was not impaired in $\Delta 36$ mice (Fig. 5).

In addition to PKA, AKAP150 also binds PKC and calcineurin (Coghlan et al., 1995; Klauck et al., 1996; Oliveria et al., 2003). Both of these enzymes control the phosphorylation and functional status of TRPV1 (Bhave and Gereau, 2004; Tominaga and Tominaga, 2005). It is therefore likely that AKAP150 integrates multiple enzymatic activities directed at TRPV1 to ensure highly localized and efficient regulation of the receptor phosphorylation. Another intriguing possibility is that AKAP150 links TRPV1 and PKA to receptors for $\mathrm{PGE}_{2}$ and other inflammatory mediators. The ability of AKAPs to bring receptors and their effectors together with other signaling components is not unprecedented. For example, AKAP79/150 is central for the assembly and function of a multiprotein complex consisting of $\beta$-adrenergic receptor, $\mathrm{G}_{\mathrm{s}}$-protein, adenylyl cyclase, AKAP79/150, and L-type $\mathrm{Ca}^{2+}$ channels (Gao et al., 1997; Davare et al., 2001; Hall et al., 2007). Another example is an AKAP150 signaling complex that couples acetylcholine muscarinic receptors with M-type (KCNQ2/3) $\mathrm{K}^{+}$ channels via $\mathrm{G}_{\mathrm{q}}$-proteins and PKC (Hoshi et al., 2003). Such molecular arrangements enable highly specific receptor-toeffector signaling despite the broad substrate specificities of PKA and PKC. Future studies will determine whether similar receptorto-effector multiprotein signaling complexes are assembled around AKAP150 and TRPV1 to regulate the phosphorylation and activity of the capsaicin receptor.

TRPV1 phosphorylation has multiple functional consequences. Several inflammatory mediators, such as bradykinin, serotonin, and ATP, as well as pharmacological activators of PKA and $\mathrm{PKC}$, reduce threshold temperature of heat-activated currents in sensory neurons and in TRPV1-expressing HEK293 cells via PKA- and PKC-dependent phosphorylation of the receptor (Tominaga et al., 2001; Rathee et al., 2002; Sugiura et al., 2002, 2004; Moriyama et al., 2005). This, in turn, can contribute to thermal hyperalgesia in response to tissue injury or inflammation observed in animal models (Caterina et al., 2000; Davis et al., 2000). A similar mechanism is likely involved in the development of $\mathrm{PGE}_{2}$-induced thermal hyperalgesia (Malmberg et al., 1997; Yang and Gereau, 2002; Moriyama et al., 2005). Indeed, we found that $\mathrm{PGE}_{2}$ decreased the threshold temperature of heat-activated currents by $\sim 8^{\circ} \mathrm{C}$ in mouse DRG neurons and that this response was partially mediated by AKAP150-anchored PKA (Fig. 9). A similar $\mathrm{PGE}_{2}$-induced shift in temperature dependence was reported in TRPV1-expressing HEK293 cells (Moriyama et al., 2005).

Another consequence of TRPV1 phosphorylation is its reduced desensitization, which can facilitate function of the receptor during continuous stimulation by protons in inflamed tissue and might be responsible for chronic pain associated with arthritis, irritable bowel syndrome, and bone cancer (Ghilardi et al., 2005; Jones et al., 2005; Keeble et al., 2005; Szabo et al., 2005). Enhanced $\mathrm{Ca}^{2+}$ influx through phosphorylated TRPV1 can also contribute to facilitated release of substance $\mathrm{P}$ and calcitonin gene-related peptide from peripheral nociceptive terminals and to the development of neurogenic inflammation (Richardson and Vasko, 2002). Thus, phosphorylation of TRPV1 triggers a concerted activation of multiple signaling pathways that lead to increased nociceptor excitability and pain hypersensitivity. Accordingly, targeting the TRPV1 phosphorylation machinery, and specifically the TRPV1-AKAP150-PKA interaction, may help to selectively alleviate the hyperalgesic action of TRPV1 while minimally affecting such physiological functions of TRPV1 as thermosensation and thermoregulation (Caterina et al., 2000; Gavva et al., 2007). Our finding that disruption of the AKAP150-PKA complex diminishes $\mathrm{PGE}_{2}$-induced thermal hyperalgesia but does not affect thermal sensitivity under basal conditions (Fig. $9 F)$ supports this concept.

In summary, we have shown that, in mouse DRG neurons, AKAP150 is a major PKA-anchoring protein involved in $\mathrm{PGE}_{2} /$ PKA-dependent TRPV1 modulation. AKAP150 may prove to serve as a molecular hub for the TRPV1 phosphorylation complex, thereby contributing to the specificity and efficiency with which the receptor is regulated by inflammatory mediators and their downstream signaling pathways.

\section{References}

Beene DL, Scott JD (2007) A-kinase anchoring proteins take shape. Curr Opin Cell Biol 19:192-198.

Bhave G, Gereau IV RW (2004) Posttranslational mechanisms of peripheral sensitization. J Neurobiol 61:88-106.

Bhave G, Zhu W, Wang H, Brasier DJ, Oxford GS, Gereau IV RW (2002) cAMP-dependent protein kinase regulates desensitization of the capsaicin receptor (VR1) by direct phosphorylation. Neuron 35:721-731.

Bhave G, Hu HJ, Glauner KS, Zhu W, Wang H, Brasier DJ, Oxford GS, Gereau IV RW (2003) Protein kinase C phosphorylation sensitizes but does not activate the capsaicin receptor transient receptor potential vanilloid 1 (TRPV1). Proc Natl Acad Sci USA 100:12480-12485.

Cantrell AR, Tibbs VC, Yu FH, Murphy BJ, Sharp EM, Qu Y, Catterall WA, Scheuer T (2002) Molecular mechanism of convergent regulation of brain $\mathrm{Na}^{+}$channels by protein kinase $\mathrm{C}$ and protein kinase $\mathrm{A}$ anchored to AKAP-15. Mol Cell Neurosci 21:63-80.

Carr DW, Stofko-Hahn RE, Fraser ID, Cone RD, Scott JD (1992) Localization of the cAMP-dependent protein kinase to the postsynaptic densities by A-kinase anchoring proteins. Characterization of AKAP 79. J Biol Chem 267:16816-16823.

Caterina MJ, Julius D (2001) The vanilloid receptor: a molecular gateway to the pain pathway. Annu Rev Neurosci 24:487-517.

Caterina MJ, Schumacher MA, Tominaga M, Rosen TA, Levine JD, Julius D (1997) The capsaicin receptor: a heat-activated ion channel in the pain pathway. Nature 389:816-824.

Caterina MJ, Leffler A, Malmberg AB, Martin WJ, Trafton J, Petersen-Zeitz KR, Koltzenburg M, Basbaum AI, Julius D (2000) Impaired nociception and pain sensation in mice lacking the capsaicin receptor. Science 288:306-313.

Chai S, Li M, Lan J, Xiong ZG, Saugstad JA, Simon RP (2007) A kinaseanchoring protein 150 and calcineurin are involved in regulation of acid sensing ion channels ASIC1a and ASIC2a. J Biol Chem 282:22668-22677.

Cholewinski A, Burgess GM, Bevan S (1993) The role of calcium in capsaicin-induced desensitization in rat cultured dorsal root ganglion neurons. Neuroscience 55:1015-1023.

Coghlan VM, Perrino BA, Howard M, Langeberg LK, Hicks JB, Gallatin WM, Scott JD (1995) Association of protein kinase A and protein phosphatase 2B with a common anchoring protein. Science 267:108-111.

Colledge M, Dean RA, Scott GK, Langeberg LK, Huganir RL, Scott JD (2000) Targeting of PKA to glutamate receptors through a MAGUK-AKAP complex. Neuron 27:107-119.

Cui M, Honore P, Zhong C, Gauvin D, Mikusa J, Hernandez G, Chandran P, Gomtsyan A, Brown B, Bayburt EK, Marsh K, Bianchi B, McDonald H, Niforatos W, Neelands TR, Moreland RB, Decker MW, Lee CH, Sullivan JP, Faltynek CR (2006) TRPV1 receptors in the CNS play a key role in broad-spectrum analgesia of TRPV1 antagonists. J Neurosci 26:9385-9393.

Davare MA, Avdonin V, Hall DD, Peden EM, Burette A, Weinberg RJ, Horne MC, Hoshi T, Hell JW (2001) A beta 2 adrenergic receptor signaling complex assembled with the $\mathrm{Ca}^{2+}$ channel Cav1.2. Science 293:98-101.

Davis JB, Gray J, Gunthorpe MJ, Hatcher JP, Davey PT, Overend P, Harries MH, Latcham J, Clapham C, Atkinson K, Hughes SA, Rance K, Grau E, Harper AJ, Pugh PL, Rogers DC, Bingham S, Randall A, Sheardown SA 
(2000) Vanilloid receptor-1 is essential for inflammatory thermal hyperalgesia. Nature 405:183-187.

Dell'Acqua ML, Smith KE, Gorski JA, Horne EA, Gibson ES, Gomez LL (2006) Regulation of neuronal PKA signaling through AKAP targeting dynamics. Eur J Cell Biol 85:627-633.

Fraser ID, Tavalin SJ, Lester LB, Langeberg LK, Westphal AM, Dean RA, Marrion NV, Scott JD (1998) A novel lipid-anchored A-kinase anchoring protein facilitates cAMP-responsive membrane events. EMBO J 17:2261-2272.

Fraser ID, Cong M, Kim J, Rollins EN, Daaka Y, Lefkowitz RJ, Scott JD (2000) Assembly of an A kinase-anchoring protein-beta(2)-adrenergic receptor complex facilitates receptor phosphorylation and signaling. Curr Biol 10:409-412.

Gao TY, Yatani A, Dellacqua ML, Sako H, Green SA, Dascal N, Scott JD, Hosey MM (1997) Camp-dependent regulation of cardiac L-type $\mathrm{Ca}^{2+}$ channels requires membrane targeting of PKA and phosphorylation of channel subunits. Neuron 19:185-196.

Gavva NR, Tamir R, Qu Y, Klionsky L, Zhang TJ, Immke D, Wang J, Zhu D, Vanderah TW, Porreca F, Doherty EM, Norman MH, Wild KD, Bannon AW, Louis JC, Treanor JJ (2005) AMG 9810 [(E)-3-(4-t-butylphenyl)$\mathrm{N}$-(2,3-dihydrobenzo[b] [1,4] dioxin-6-yl)acrylamide], a novel vanilloid receptor 1 (TRPV1) antagonist with antihyperalgesic properties. J Pharmacol Exp Ther 313:474-484.

Gavva NR, Bannon AW, Surapaneni S, Hovland Jr DN, Lehto SG, Gore A, Juan T, Deng H, Han B, Klionsky L, Kuang R, Le A, Tamir R, Wang J, Youngblood B, Zhu D, Norman MH, Magal E, Treanor JJ, Louis JC (2007) The vanilloid receptor TRPV1 is tonically activated in vivo and involved in body temperature regulation. J Neurosci 27:3366-3374.

Ghilardi JR, Rohrich H, Lindsay TH, Sevcik MA, Schwei MJ, Kubota K, Halvorson KG, Poblete J, Chaplan SR, Dubin AE, Carruthers NI, Swanson D, Kuskowski M, Flores CM, Julius D, Mantyh PW (2005) Selective blockade of the capsaicin receptor TRPV1 attenuates bone cancer pain. J Neurosci 25:3126-3131.

Gold MS, Flake NM (2005) Inflammation-mediated hyperexcitability of sensory neurons. Neurosignals 14:147-157.

Gomez LL, Alam S, Smith KE, Horne E, Dell'Acqua ML (2002) Regulation of A-kinase anchoring protein 79/150-cAMP-dependent protein kinase postsynaptic targeting by NMDA receptor activation of calcineurin and remodeling of dendritic actin. J Neurosci 22:7027-7044.

Gray PC, Tibbs VC, Catterall WA, Murphy BJ (1997) Identification of a $15-\mathrm{kDa}$ cAMP-dependent protein kinase-anchoring protein associated with skeletal muscle L-type calcium channels. J Biol Chem 272:6297-6302.

Gray PC, Johnson BD, Westenbroek RE, Hays LG, Yates III JR, Scheuer T, Catterall WA, Murphy BJ (1998) Primary structure and function of an A kinase anchoring protein associated with calcium channels. Neuron 20:1017-1026.

Greffrath W, Kirschstein T, Nawrath H, Treede R (2001) Changes in cytosolic calcium in response to noxious heat and their relationship to vanilloid receptors in rat dorsal root ganglion neurons. Neuroscience 104:539-550.

Grynkiewicz G, Poenie M, Tsien RY (1985) A new generation of $\mathrm{Ca}^{2+}$ indicators with greatly improved fluorescence properties. J Biol Chem 260:3440-3450.

Gu Q, Kwong K, Lee LY (2003) $\mathrm{Ca}^{2+}$ transient evoked by chemical stimulation is enhanced by PGE2 in vagal sensory neurons: role of cAMP/PKA signaling pathway. J Neurophysiol 89:1985-1993.

Guo A, Vulchanova L, Wang J, Li X, Elde R (1999) Immunocytochemical localization of the vanilloid receptor 1 (VR1): relationship to neuropeptides, the P2X3 purinoceptor and IB4 binding sites. Eur J Neurosci 11:946-958.

Hall DD, Davare MA, Shi M, Allen ML, Weisenhaus M, McKnight GS, Hell JW (2007) Critical role of cAMP-dependent protein kinase anchoring to the L-type calcium channel Cav1.2 via A-kinase anchor protein 150 in neurons. Biochemistry 46:1635-1646.

Hargreaves K, Dubner R, Brown F, Flores C, Joris J (1988) A new and sensitive method for measuring thermal nociception in cutaneous hyperalgesia. Pain 32:77-88.

Hingtgen CM, Waite KJ, Vasko MR (1995) Prostaglandins facilitate peptide release from rat sensory neurons by activating the adenosine $3^{\prime}, 5^{\prime}$-cyclic monophosphate transduction cascade. J Neurosci 15:5411-5419.

Hjerling-Leffler J, Alqatari M, Ernfors P, Koltzenburg M (2007) Emergence of functional sensory subtypes as defined by transient receptor potential channel expression. J Neurosci 27:2435-2443.

Holz GG, Kang G, Harbeck M, Roe MW, Chepurny OG (2006) Cell physiology of cAMP sensor Epac. J Physiol (Lond) 577:5-15.

Hoshi N, Zhang JS, Omaki M, Takeuchi T, Yokoyama S, Wanaverbecq N, Langeberg LK, Yoneda Y, Scott JD, Brown DA, Higashida H (2003) AKAP150 signaling complex promotes suppression of the M-current by muscarinic agonists. Nat Neurosci 6:564-571.

Hu H-J, Bhave G, Gereau IV RW (2002) Prostaglandin and protein kinase A-dependent modulation of vanilloid receptor function by metabotropic glutamate receptor 5: potential mechanism for thermal hyperalgesia. J Neurosci 22:7444-7452.

Huang LJ, Wang L, Ma Y, Durick K, Perkins G, Deerinck TJ, Ellisman MH, Taylor SS (1999) NH2-Terminal targeting motifs direct dual specificity A-kinase-anchoring protein 1 (D-AKAP1) to either mitochondria or endoplasmic reticulum. J Cell Biol 145:951-959.

Hucho TB, Dina OA, Levine JD (2005) Epac mediates a cAMP-to-PKC signaling in inflammatory pain: an isolectin $\mathrm{B}^{+}{ }^{+}$neuron-specific mechanism. J Neurosci 25:6119-6126.

Hulme JT, Lin TW, Westenbroek RE, Scheuer T, Catterall WA (2003) Betaadrenergic regulation requires direct anchoring of PKA to cardiac CaV1.2 channels via a leucine zipper interaction with A kinase-anchoring protein 15. Proc Natl Acad Sci USA 100:13093-13098.

Hundsrucker C, Rosenthal W, Klussmann E (2006) Peptides for disruption of PKA anchoring. Biochem Soc Trans 34:472-473.

Immke DC, Gavva NR (2006) The TRPV1 receptor and nociception. Semin Cell Dev Biol 17:582-591.

Jones III RC, Xu L, Gebhart GF (2005) The mechanosensitivity of mouse colon afferent fibers and their sensitization by inflammatory mediators require transient receptor potential vanilloid 1 and acid-sensing ion channel 3. J Neurosci 25:10981-10989.

Julius D, Basbaum AI (2001) Molecular mechanisms of nociception. Nature 413:203-210.

Karai LJ, Russell JT, Iadarola MJ, Olah Z (2004) Vanilloid receptor 1 regulates multiple calcium compartments and contributes to $\mathrm{Ca}^{2+}$-induced $\mathrm{Ca}^{2+}$ release in sensory neurons. J Biol Chem 279:16377-16387.

Keeble J, Russell F, Curtis B, Starr A, Pinter E, Brain SD (2005) Involvement of transient receptor potential vanilloid 1 in the vascular and hyperalgesic components of joint inflammation. Arthritis Rheum 52:3248-3256.

Kim S, Kang C, Shin CY, Hwang SW, Yang YD, Shim WS, Park MY, Kim E, Kim M, Kim BM, Cho H, Shin Y, Oh U (2006) TRPV1 recapitulates native capsaicin receptor in sensory neurons in association with Fasassociated factor 1. J Neurosci 26:2403-2412.

Klauck TM, Faux MC, Labudda K, Langeberg LK, Jaken S, Scott JD (1996) Coordination of three signaling enzymes by AKAP79, a mammalian scaffold protein. Science 271:1589-1592.

Koplas PA, Rosenberg RL, Oxford GS (1997) The role of calcium in the desensitization of capsaicin responses in rat dorsal root ganglion neurons. J Neurosci 17:3525-3537.

Kurokawa J, Motoike HK, Rao J, Kass RS (2004) Regulatory actions of the A-kinase anchoring protein Yotiao on a heart potassium channel downstream of PKA phosphorylation. Proc Natl Acad Sci USA 101:16374-16378.

Lin CR, Amaya F, Barrett L, Wang H, Takada J, Samad TA, Woolf CJ (2006) Prostaglandin E2 receptor EP4 contributes to inflammatory pain hypersensitivity. J Pharmacol Exp Ther 319:1096-1103.

Lin JW, Wyszynski M, Madhavan R, Sealock R, Kim JU, Sheng M (1998) Yotiao, a novel protein of neuromuscular junction and brain that interacts with specific splice variants of NMDA receptor subunit NR1. J Neurosci 18:2017-2027.

Liu M, Liu MC, Magoulas C, Priestley JV, Willmott NJ (2003) Versatile regulation of cytosolic $\mathrm{Ca}^{2+}$ by vanilloid receptor I in rat dorsal root ganglion neurons. J Biol Chem 278:5462-5472.

Lopshire JC, Nicol GD (1998) The cAMP transduction cascade mediates the prostaglandin E2 enhancement of the capsaicin-elicited current in rat sensory neurons: whole-cell and single-channel studies. J Neurosci 18:6081-6092.

Lu Y, Allen M, Halt AR, Weisenhaus M, Dallapiazza RF, Hall DD, Usachev YM, McKnight GS, Hell JW (2007) Age-dependent requirement of AKAP150-anchored PKA and GluR2-lacking AMPA receptors in LTP. EMBO J 26:4879-4890.

Malin SA, Molliver DC, Koerber HR, Cornuet P, Frye R, Albers KM, Davis 
BM (2006) Glial cell line-derived neurotrophic factor family members sensitize nociceptors in vitro and produce thermal hyperalgesia in vivo. J Neurosci 26:8588-8599.

Malmberg AB, Brandon EP, Idzerda RL, Liu H, McKnight GS, Basbaum AI (1997) Diminished inflammation and nociceptive pain with preservation of neuropathic pain in mice with a targeted mutation of the type I regulatory subunit of cAMP-dependent protein kinase. J Neurosci 17:7462-7470.

Mandadi S, Numazaki M, Tominaga M, Bhat MB, Armati PJ, Roufogalis BD (2004) Activation of protein kinase C reverses capsaicin-induced calcium-dependent desensitization of TRPV1 ion channels. Cell Calcium 35:471-478.

Mandadi S, Tominaga T, Numazaki M, Murayama N, Saito N, Armati PJ, Roufogalis BD, Tominaga M (2006) Increased sensitivity of desensitized TRPV1 by PMA occurs through PKCepsilon-mediated phosphorylation at S800. Pain 123:106-116.

Mohapatra DP, Nau C (2003) Desensitization of capsaicin-activated currents in the vanilloid receptor TRPV1 is decreased by the cyclic AMPdependent protein kinase pathway. J Biol Chem 278:50080-50090.

Mohapatra DP, Nau C (2005) Regulation of $\mathrm{Ca}^{2+}$-dependent desensitization in the vanilloid receptor TRPV1 by calcineurin and cAMPdependent protein kinase. J Biol Chem 280:13424-13432.

Moriyama T, Higashi T, Togashi K, Iida T, Segi E, Sugimoto Y, Tominaga T, Narumiya S, Tominaga M (2005) Sensitization of TRPV1 by EP1 and IP reveals peripheral nociceptive mechanism of prostaglandins. Mol Pain $1: 3$.

Nagy I, Santha P, Jancso G, Urban L (2004) The role of the vanilloid (capsaicin) receptor (TRPV1) in physiology and pathology. Eur J Pharmacol 500:351-369.

Nauert JB, Klauck TM, Langeberg LK, Scott JD (1997) Gravin, an autoantigen recognized by serum from myasthenia gravis patients, is a kinase scaffold protein. Curr Biol 7:52-62.

Negri L, Lattanzi R, Giannini E, Colucci M, Margheriti F, Melchiorri P, Vellani V, Tian H, De Felice M, Porreca F (2006) Impaired nociception and inflammatory pain sensation in mice lacking the prokineticin receptor PKR1: focus on interaction between PKR1 and the capsaicin receptor TRPV1 in pain behavior. J Neurosci 26:6716-6727.

Numazaki M, Tominaga T, Toyooka H, Tominaga M (2002) Direct phosphorylation of capsaicin receptor VR1 by protein kinase Cepsilon and identification of two target serine residues. J Biol Chem 277:13375-13378.

Oliveria SF, Gomez LL, Dell'Acqua ML (2003) Imaging kinase-AKAP79phosphatase scaffold complexes at the plasma membrane in living cells using FRET microscopy. J Cell Biol 160:101-112.

Park KA, Vasko MR (2005) Lipid mediators of sensitivity in sensory neurons. Trends Pharmacol Sci 26:571-577.

Piontek J, Brandt R (2003) Differential and regulated binding of cAMPdependent protein kinase and protein kinase $\mathrm{C}$ isoenzymes to gravin in human model neurons: evidence that gravin provides a dynamic platform for the localization for kinases during neuronal development. J Biol Chem 278:38970-38979.

Premkumar LS, Ahern GP (2000) Induction of vanilloid receptor channel activity by protein kinase C. Nature 408:985-990.

Premkumar LS, Qi ZH, Van Buren J, Raisinghani M (2004) Enhancement of potency and efficacy of NADA by PKC-mediated phosphorylation of vanilloid receptor. J Neurophysiol 91:1442-1449.

Rathee PK, Distler C, Obreja O, Neuhuber W, Wang GK, Wang SY, Nau C, Kress M (2002) PKA/AKAP/VR-1 module: a common link of $\mathrm{G}_{\mathrm{s}}{ }^{-}$ mediated signaling to thermal hyperalgesia. J Neurosci 22:4740-4745.

Richardson JD, Vasko MR (2002) Cellular mechanisms of neurogenic inflammation. J Pharmacol Exp Ther 302:839-845.

Savidge JR, Ranasinghe SP, Rang HP (2001) Comparison of intracellular calcium signals evoked by heat and capsaicin in cultured rat dorsal root ganglion neurons and in a cell line expressing the rat vanilloid receptor, VR1. Neuroscience 102:177-184.

Shih M, Lin F, Scott JD, Wang HY, Malbon CC (1999) Dynamic complexes of beta2-adrenergic receptors with protein kinases and phosphatases and the role of gravin. J Biol Chem 274:1588-1595.

Southall MD, Vasko MR (2001) Prostaglandin receptor subtypes, EP3C and EP4, mediate the prostaglandin E2-induced cAMP production and sensitization of sensory neurons. J Biol Chem 276:16083-16091.

Sugiura T, Tominaga M, Katsuya H, Mizumura K (2002) Bradykinin lowers the threshold temperature for heat activation of vanilloid receptor 1 . J Neurophysiol 88:544-548.

Sugiura T, Bielefeldt K, Gebhart GF (2004) TRPV1 function in mouse colon sensory neurons is enhanced by metabotropic 5-hydroxytryptamine receptor activation. J Neurosci 24:9521-9530.

Svensson CI, Yaksh TL (2002) The spinal phospholipase-cyclooxygenaseprostanoid cascade in nociceptive processing. Annu Rev Pharmacol Toxicol 42:553-583.

Szabo A, Helyes Z, Sandor K, Bite A, Pinter E, Nemeth J, Banvolgyi A, Bolcskei K, Elekes K, Szolcsanyi J (2005) Role of transient receptor potential vanilloid 1 receptors in adjuvant-induced chronic arthritis: in vivo study using gene-deficient mice. J Pharmacol Exp Ther 314:111-119.

Szallasi A, Cruz F, Geppetti P (2006) TRPV1: a therapeutic target for novel analgesic drugs? Trends Mol Med 12:545-554.

Tao J, Wang HY, Malbon CC (2003) Protein kinase A regulates AKAP250 (gravin) scaffold binding to the beta2-adrenergic receptor. EMBO J 22:6419-6429.

Tavalin SJ, Colledge M, Hell JW, Langeberg LK, Huganir RL, Scott JD (2002) Regulation of GluR1 by the A-kinase anchoring protein 79 (AKAP79) signaling complex shares properties with long-term depression. J Neurosci 22:3044-3051.

Tibbs VC, Gray PC, Catterall WA, Murphy BJ (1998) AKAP15 anchors cAMP-dependent protein kinase to brain sodium channels. J Biol Chem 273:25783-25788.

Tominaga M, Tominaga T (2005) Structure and function of TRPV1. Pflügers Arch 451:143-150.

Tominaga M, Caterina MJ, Malmberg AB, Rosen TA, Gilbert H, Skinner K, Raumann BE, Basbaum AI, Julius D (1998) The cloned capsaicin receptor integrates multiple pain-producing stimuli. Neuron 21:531-543.

Tominaga M, Wada M, Masu M (2001) Potentiation of capsaicin receptor activity by metabotropic ATP receptors as a possible mechanism for ATPevoked pain and hyperalgesia. Proc Natl Acad Sci USA 98:6951-6956.

Trotter KW, Fraser ID, Scott GK, Stutts MJ, Scott JD, Milgram SL (1999) Alternative splicing regulates the subcellular localization of A-kinase anchoring protein 18 isoforms. J Cell Biol 147:1481-1492.

Vellani V, Mapplebeck S, Moriondo A, Davis JB, McNaughton PA (2001) Protein kinase $\mathrm{C}$ activation potentiates gating of the vanilloid receptor VR1 by capsaicin, protons, heat and anandamide. J Physiol (Lond) 534:813-825.

Wang L, Sunahara RK, Krumins A, Perkins G, Crochiere ML, Mackey M, Bell S, Ellisman MH, Taylor SS (2001) Cloning and mitochondrial localization of full-length D-AKAP2, a protein kinase A anchoring protein. Proc Natl Acad Sci USA 98:3220-3225.

Wang S, Davis BM, Zwick M, Waxman SG, Albers KM (2006) Reduced thermal sensitivity and Nav1.8 and TRPV1 channel expression in sensory neurons of aged mice. Neurobiol Aging 27:895-903.

Westphal RS, Tavalin SJ, Lin JW, Alto NM, Fraser ID, Langeberg LK, Sheng M, Scott JD (1999) Regulation of NMDA receptors by an associated phosphatase-kinase signaling complex. Science 285:93-96.

Wong W, Scott JD (2004) AKAP signalling complexes: focal points in space and time. Nat Rev Mol Cell Biol 5:959-970.

Yang D, Gereau IV RW (2002) Peripheral group II metabotropic glutamate receptors (mGluR2/3) regulate prostaglandin E2-mediated sensitization of capsaicin responses and thermal nociception. J Neurosci 22:6388-6393.

Zwick M, Davis BM, Woodbury CJ, Burkett JN, Koerber HR, Simpson JF, Albers KM (2002) Glial cell line-derived neurotrophic factor is a survival factor for isolectin B4-positive, but not vanilloid receptor 1-positive, neurons in the mouse. J Neurosci 22:4057-4065. 